\title{
Post-collisional magmatism in the central East African Orogen: the Maevarano Suite of north Madagascar
}

\author{
K. M Goodenough ${ }^{1, \#}$, R. J. Thomas ${ }^{2}$, B. De Waele ${ }^{2 *}$, R. M. Key ${ }^{1}$, D.I. Schofield ${ }^{2}$, W. \\ Bauer $^{2 * *}$, R. M. Tucker ${ }^{3}$, J-M. Rafahatelo ${ }^{4}$, M. Rabarimanana ${ }^{4}$, A.V. Ralison ${ }^{4}$ and T. \\ Randriamananjara ${ }^{4}$ \\ ${ }^{1}$ British Geological Survey, Murchison House, Edinburgh, EH9 3LA, U.K \\ ${ }^{2}$ British Geological Survey, Keyworth, NG12 5GG U.K. \\ ${ }^{3}$ United States Geological Survey, Reston, Va,20192 USA \\ ${ }^{4}$ Projet de Gouvernance des Ressources Minières, Ampandrianomby, Antananarivo, Madagascar \\ * Present address : SRK Consulting, Perth, Western Australia \\ ** Present address: Geologisches Institut, RWTH-Aachen, 52056 Aachen, Germany \\ \#: Corresponding author, kmgo@bgs.ac.uk Tel: 00441316500272
}

\section{Abstract}

Late tectonic, post-collisional granite suites are a feature of many parts of the Late Neoproterozoic to Cambrian East African Orogen (EAO), where they are generally attributed to late extensional collapse of the orogen, accompanied by high heat flow and asthenospheric uprise. The Maevarano Suite comprises voluminous plutons which were emplaced in some of the tectonostratigraphic terranes of northern Madagascar, in the central part of the EAO, following collision and assembly during a major orogeny at ca. $550 \mathrm{Ma}$. The suite comprises three main magmatic phases: a minor early phase of foliated gabbros, quartz diorites, and granodiorites; a main phase of large batholiths of porphyritic granitoids and charnockites; and a late phase of small-scale plutons and sheets of monzonite, syenite, leucogranite and microgranite. The main phase intrusions tend to be massive, but with variably foliated margins. New U-Pb SHRIMP zircon data show that the whole suite was emplaced between ca. 537 and 522 Ma. Geochemically, all the rocks of the suite are enriched in the LILE, especially K, and the LREE, but are relatively 
29 depleted in $\mathrm{Nb}$, Ta and the HREE. These characteristics are typical of post-collisional

30 granitoids in the EAO and many other orogenic belts. It is proposed that the Maevarano

31 Suite magmas were derived by melting of sub-continental lithospheric mantle that had

32 been enriched in the LILE during earlier subduction events. The melting occurred during

33 lithospheric delamination, which was associated with extensional collapse of the East

34 African Orogen.

\section{Keywords}

Madagascar; Maevarano Suite; post-collisional magmatism; East African Orogen

\section{Introduction}

The island of Madagascar comprises a collage of Precambrian basement terranes,

42 terranes were juxtaposed during the Neoproterozoic to Cambrian (Pan-African) East

43 African and Malagasy orogenies (Collins and Pisarevsky, 2005). The East African

44 Orogen (EAO; Fig. 1) extends from Egypt in the north to Antarctica in the south (Stern,

45 1994; Meert, 2003; Jacobs and Thomas, 2004) and represents the collision zone between

46 Neoproterozoic India, the Congo-Tanzania-Bangweulu block, and the Saharan

47 metacraton (Meert, 2003; Collins and Pisarevsky, 2005; Collins, 2006). Madagascar lies

48 in the heart of the EAO, and its basement rocks have been studied from a number of

49 viewpoints including metamorphic histories (e.g. Buchwaldt et al., 2003; Jöns et al.,

50 2006); structural geology (Collins et al., 2003a, b; Tucker et al., 2007; Thomas et al.,

512009 ) and magmatic processes (Nédélec et al., 1995; Paquette and Nédélec, 1998; Meert

52 et al., 2001). In this paper we focus on the post-collisional intrusions of the Maevarano

53 Suite of northern Madagascar, in order to understand the lithospheric processes related to

54 the latter stages of this major orogenic event. Our work is the result of a major World

55 Bank sponsored project, which involved re-mapping and sampling the basement rocks of

56 northern Madagascar, undertaken by a consortium of the British Geological Survey

57 (BGS), the United States Geological Survey (USGS), and GLW Conseil (GLW). The 
results were presented in the form of geological maps of various scales and an unpublished explanation (BGS-USGS-GLW, 2008).

Voluminous post-collisional granitoids are a major feature of the EAO (Black and

61 Liégeois, 1993; Küster and Harms, 1998; Meert, 2003; Jacobs et al., 2008). They are

62 typically alkaline and metaluminous in composition, and can be broadly characterised as

63 A-type granitoids under the classification of Whalen et al. (1987). In the southern part of

64 the EAO, in East Antarctica and Mozambique, peak metamorphism associated with

65 collision-induced crustal thickening occurred at ca. $555 \mathrm{Ma}$ (Bingen et al., 2009) and

66 post-collisional magmas were emplaced between ca. 530 and $485 \mathrm{Ma}$, with a pulse of

67 voluminous granitoid and charnockite magmatism at 510 - 500 Ma (Jacobs et al., 2008).

68 In central Madagascar, alkaline granite sheets (termed 'stratoid granites') have been dated

69 at ca. $630 \mathrm{Ma}$ (Nédélec et al., 1995; Paquette and Nédélec, 1998) and were considered to

70 be post-collisional, following a high-grade metamorphic episode at ca. $650 \mathrm{Ma}$ (Meert et

71 al., 2003). In northern and central Madagascar, prograde metamorphism occurred

72 between 570 and 520 Ma (Jöns et al., 2006; Tucker et al., 2007), and a number of post-

73 collisional plutons were emplaced during the period 550 - 520 Ma (Tucker et al., 1999;

74 Kröner et al., 1999, 2000; Meert et al., 2001; Buchwaldt et al., 2003). In the northern part

75 of the EAO, many post-collisional potassic granitoids were emplaced, following crustal

76 thickening, between 630 and $470 \mathrm{Ma}$ (Küster and Harms, 1998 (Sudan, Ethiopia and

77 Somalia); Be'eri-Shlevin et al, 2009a (Israel and Egypt)). However, it seems that

78 granitoids of this type are less abundant in the central EAO, in Mozambique north of the

79 Lurio Belt (Jacobs et al., 2008) and in Tanzania, where high-grade metamorphism is also

80 recorded between 655 and $520 \mathrm{Ma}$ (Möller et al., 2000; Johnson et al., 2005). The cause

81 of this localisation of post-collisional granitoids in certain areas of the EAO remains

82 uncertain, although Jacobs et al. (2008) have suggested that it may be related to partial

83 lithospheric delamination in specific areas of the orogen. However, it is notable that post-

84 collisional granitoids in the EAO are commonly associated both spatially and temporally

85 with major shear zones; examples of such magmatic events occurred in the ca. $550 \mathrm{Ma}$

86 Angavo shear zone of central Madagascar (Grégoire et al., 2009), after ca. $530 \mathrm{Ma}$ in the

87 Lurio Belt of Mozambique (Bingen et al., 2009) and at 570 - $520 \mathrm{Ma}$ in the Palghat-

88 Cauvery shear zone of southern India (Santosh et al., 2005). 


\section{Geology of northern Madagascar}

The Precambrian basement of northern Madagascar consists of four main tectonic

93 units (Collins and Windley, 2002; Collins, 2006, Thomas et al., 2009). The oldest of

94 these is the Antongil Craton, on the north-east coast (Fig. 2), which comprises Archaean

95 orthogneisses formed at ca. $3200 \mathrm{Ma}$ and intruded by granitoids at ca. $2500 \mathrm{Ma}$ (Tucker

96 et al., 1999; Paquette et al., 2003). The craton was intruded by a Palaeoproterozoic mafic

97 suite, but was apparently unaffected by Neoproterozoic magmatism (BGS-USGS-GLW, 98 2008).

99 Dominating most of central Madagascar, the Antananarivo Craton (Fig. 2),

100 comprises Neoarchaean orthogneisses and supracrustal rocks (2520 - 2500 Ma; Tucker et

101 al., 1999; Kröner et al., 2000), including the Tsaratanana Sheets, which are generally

102 considered to be allochthonous (Collins et al., 2003a). The Antananarivo Craton is

103 tectonically overlain in the west by Proterozoic metasedimentary rocks of the Itremo and

104 Ikalamavony groups (Cox et al., 1998; Collins, 2006). The gneisses of the Antananarivo

105 Craton and the overlying metasedimentary rocks were intruded at $820-720 \mathrm{Ma}$ by

106 extensive granitoid plutons (Handke et al., 1999; Tucker et al., 1999; Kröner et al., 2000),

107 and evidence for earlier magmatism at ca.1000 Ma has recently been reported (Tucker et

108 al., 2007). The northern part of the Antananarivo Craton was intruded by 'stratoid

109 granites' at ca. $630 \mathrm{Ma}$ (Nédélec et al., 1995; Paquette and Nédélec, 1998). High-grade

110 metamorphism, due to crustal thickening, occurred between 570 and $520 \mathrm{Ma}$ (Kröner et

111 al., 2000; de Wit et al., 2001; Tucker et al., 2007; Grégoire et al., 2009) and post-

112 collisional granites were emplaced during the period 550 - 530 Ma (Tucker et al., 1999;

113 Kröner et al., 1999, 2000; Meert et al., 2001).

114 In the northernmost part of the island, the Bemarivo Belt (Fig. 2) comprises two

115 distinct Proterozoic metamorphosed volcano-sedimentary sequences intruded by

116 Neoproterozoic arc-related plutons (Thomas et al., 2009). The southern part of the belt

117 consists of a sequence of high-grade metasedimentary rocks (Sahantaha Group), which

118 were derived from a Palaeoproterozoic source, and were intruded at $750 \mathrm{Ma}$ by an 
119 extensive suite of plutonic rocks (Thomas et al., 2009). The northern part comprises two

120 ca. 750 - 720 Ma metamorphosed volcano-sedimentary sequences, the high-grade

121 Milanoa Group and lower-grade Daraina Group. These supracrustal rocks are also

122 intruded by plutonic rocks, which date from between 718 and $705 \mathrm{Ma}$ (Thomas et al.,

123 2009). The components of the Bemarivo Belt are considered to have formed in an arc

124 setting, and were metamorphosed to varying grades during collision with cratonic

125 Madagascar at 560-530 Ma (Jöns et al, 2006; Thomas et al., 2009). They were

126 subsequently intruded by post-collisional granitoids, and one pluton from this suite has

127 previously been dated at ca. 520 Ma (Buchwaldt et al., 2003; Jöns et al., 2006).

128 The 'suture zone' between the Antananarivo and Antongil cratons, comprising

129 paragneisses with numerous units of mafic and ultramafic rock, has been termed the

130 'Betsimisaraka Suture Zone' (Kröner et al., 2000; Collins and Windley, 2002). Our

131 mapping (BGS-USGS-GLW, 2008) has defined a broadly equivalent terrane, the

132 Anaboriana-Manampotsy Belt, which largely lies between the Bemarivo Belt and

133 Antananarivo Craton (Fig. 2), and extends southwards roughly along the eastern side of

134 the Antananarivo Craton. This terrane consists of Neoproterozoic metasedimentary rocks

135 that underwent metamorphism and extensive migmatisation at the time of collision of the

136 Bemarivo Belt and Antananarivo Craton (BGS-USGS-GLW, 2008), and are intruded by

137 abundant post-collisional granitoids. On its northern margin, the Anaboriana-

138 Manampotsy Belt is separated from the Bemarivo Belt by a steep shear zone, the

139 Sandrakota Shear Zone. To the south, the Anaboriana-Manampotsy Belt appears to pass

140 into the major Angavo Shear Zone of Nédélec et al. (2000).

141 Between 2005 and 2008 the BGS-USGS-GLW consortium undertook a regional

142 geological survey of northern Madagascar, along with a regional stream sediment

143 sampling programme and representative rock sampling for whole-rock geochemistry and

$144 \mathrm{U}-\mathrm{Pb}$ zircon geochronology. As part of this work, the voluminous post-collisional

145 intrusions that occur within the northern part of the Antananarivo Craton, the Bemarivo

146 Belt and, most especially, the intervening Anaboriana-Manampotsy Belt, were mapped

147 and termed the 'Maevarano Suite' after the river of that name, where the various phases

148 of the suite are superbly exposed (Fig. 2, 3). Previous workers had identified many of the

149 plutons, but had not distinguished them from the foliated, Neoproterozoic and older 
150 intrusions which are also exposed in the area (e.g. Besairie, 1971; Hottin, 1972). Post-

151 collisional granitoids in the Bemarivo Belt were identified by Buchwaldt et al. (2003) in

152 the Marojejy region, but their full extent and volume has only now been recognised. The

153 geology, petrography, geochemistry, age and petrogenesis of the Maevarano Suite

154 plutons are the subject of this paper.

155 The components of the Maevarano Suite were identified under a range of names

156 by previous surveys. Most of the Maevarano Suite plutons were shown as "granites et

157 migmatites granitoïdes" and "charnockites" on the compilations of Besairie $(1964,1971)$,

158 but these also included arc-related plutonic rocks (mainly orthogneisses) in the Bemarivo

159 Belt that are now known to be older, between ca. 750 and $710 \mathrm{Ma}$ (Thomas et al., 2009).

160 The 1:2 million-scale tectonic compilation of Hottin (1972) showed the post-collisional

161 granitoids in the recently defined Anaboriana-Manampotsy Belt to be older than similar

162 intrusions in the Bemarivo Belt, which were indicated merely as "granitoïds

163 indifférenciés". Our new geological maps are thus the first to show the true extent of this

164 widespread suite of post-collisional plutons (Fig. 2, 3; BGS-USGS-GLW, 2008).

165 Previous work on the post-collisional plutons in northernmost Madagascar has

166 been limited. Medium- to coarse-grained, weakly foliated "charnockite" plutons,

167 intruding the Bemarivo Belt in the Marojejy area (Fig. 2), gave a U-Pb (single zircon

168 TIMS analysis) emplacement date of $521 \pm 4 \mathrm{Ma}$ (Buchwaldt et al., 2003). U-Pb dating

169 (in situ electron microprobe analysis of monazite) allowed Jöns et al. (2006) to identify

170 two metamorphic stages for this area: collisional metamorphism between ca. 560 and 530

$171 \mathrm{Ma}$, and peak metamorphic temperatures (possibly associated with the post-collisional

172 magmatism) between ca. 520 and 510 Ma.

173

\section{3. Field relationships of the Maevarano Suite}

175 The Maevarano Suite consists of numerous batholiths and plutons of varying size, 176 extending throughout the Bemarivo and Anaboriana-Manampotsy belts and the northern

177 part of the Antananarivo Craton (Fig. 2). The intrusions are most abundant in the

178 Anaboriana-Manampotsy Belt, where they form around 50\% of the total outcrop area.

179 The porphyritic granite and charnockite that make up the greater volume of the suite 
180 characteristically form high mountain savannah country, with large whaleback and 181 pavement outcrops (Fig. 4a). These rocks underlie parts of the high mountains (>2200 m)

182 of the Marojejy massif in north-east Madagascar, and the mountain massifs around 183 Sandra Kota, through which the Maevarano River has carved a deep gorge. Around 184 Sandra Kota, a single batholith is exposed over an area of some $15000 \mathrm{~km}^{2}$, and affords 185 excellent outcrops which constitute the "Type Area" of the suite (Fig. 3). Rocks of the 186 Maevarano Suite differ from the older intrusions in the area in that they are typically 187 weakly foliated to unfoliated, although a more intense foliation is typically developed at 188 pluton margins and within ductile shear zones (Fig 4b, c). The older intrusions of the 189 suite tend to be more pervasively foliated than the younger intrusions.

190 The plutons of the Maevarano Suite are chiefly granitic, including some 191 charnockitic (orthopyroxene-bearing) types, but range through granodiorites to 192 monzonites and syenites (generally quartz-bearing). Some minor mafic (dioritic to

193 gabbroic) intrusions, which have igneous textures, are intimately associated with the acid 194 rocks in the field (Fig. 4 e,f). The whole suite can be broadly divided into three magmatic 195 phases: an early phase of foliated intrusions, which are most commonly granodioritic; a 196 main phase of voluminous granitoid and charnockite plutons; and a late phase comprising 197 chiefly granites and monzogranites.

$198 \quad 3.1$ Early phase

199 The early phase of the Maevarano Suite includes both the most mafic and the 200 most pervasively deformed intrusions. For example, early biotite- and hornblende-bearing 201 granodioritic to monzodioritic orthogneisses form elongate intrusions that crop out in the 202 Maevarano River valley (Fig. 3). One such body has been dated for this study. The 203 Maevarano Suite also includes minor volumes of early mafic phases, including 204 homogeneous, medium- to coarse-grained, greenish-grey, foliated quartz-diorite, and 205 coarse- to medium-grained, dark-grey to blue-grey gabbro. The gabbros in particular are 206 typically associated with, and cut by, intrusions of porphyritic granite, often in complex 207 associations, with several cross-cutting phases (Fig. 4e, f). For this reason these mafic 208 intrusions are attributed to the early phase of the suite, but they have not been dated. 
209 Small pyroxenite pods occur at a few locations, though their relationship to the rest of the

210 suite is uncertain.

2113.2 Main phase

212 The most common lithology of the Maevarano Suite is very coarse-grained, fairly

213 homogeneous, pinkish, typically porphyritic, biotite \pm hornblende granite, with subhedral

214 to euhedral, pink K-feldspar megacrysts up to $2.5 \mathrm{~cm}$ in size. These granites form some

215 of the largest intrusions in the Maevarano Suite, irregular in shape and of batholithic

216 proportions. Large bodies of orthopyroxene-bearing granite are commonly associated

217 with the porphyritic granites and have been mapped as charnockite (BGS-USGS-GLW,

218 2008). Typically, they are coarse- to very coarse-grained, locally potassium feldspar- or

219 plagioclase-phyric (phenocrysts up to $2 \mathrm{~cm}$ across), and fresh samples are characterised

220 by the classic dark green colouration and resinous lustre, together with the presence of

221 macroscopic orthopyroxene (Fig. 4d). Many of these charnockite bodies occur in

222 association with pink porphyritic granite, but contacts between the two are rarely

223 exposed. Medium- to coarse-grained, non-porphyritic granitoids are also relatively

224 common, and considered to be part of the main granite-charnockite phase.

225 The central parts of the main phase plutons are typically unfoliated or weakly

226 foliated, but a fabric defined by orientation of planar minerals commonly appears towards

227 pluton margins. Locally, the porphyritic granitoids have been transformed to strongly

228 flattened augen gneisses in ductile shear zones up to several hundreds of metres wide

229 (Fig. 3). In undeformed zones, a primary, igneous flow orientation of K-feldspar

230 phenocrysts has been locally observed.

231 Enclave-rich zones are common within the Maevarano Suite granitoids. The

232 enclaves either take the form of well-defined, discoidal, magmatic enclaves, or more

233 diffuse, partially digested and feldspathised mafic xenoliths stoped from the enclosing

234 country rock gneisses. In some areas, rafts up to hundreds of metres long of country rock

235 granite and gneiss occur within the granite, particularly close to its margins. Enclaves are

236 less commonly observed within the charnockites and, where seen, tend to have much

237 higher contents of mafic minerals than those within the granites.

$238 \quad 3.3$ Late phase 
Within the Anaboriana-Manampotsy Belt, a number of later plutons intrude the porphyritic granites of the main phase (Fig. 3). In the northern part of the belt, elliptical monzogranite plutons up to $5 \mathrm{~km}$ across intrude the porphyritic granitoids, and one of

242 these has been dated during this study. These monzogranites are typically coarse-grained,

243 equigranular, weakly foliated (strongly foliated at the margins), grey to pinkish-grey, and

244 biotite- and amphibole-bearing. Syenite plutons are also reported from inaccessible

245 regions in the Bealanana area (BGS-USGS-GLW, 2008). Other intrusions belonging to

246 the late phase, which also intrude main phase plutons, include variably foliated

247 leucogranite sheets (Fig. 3), one of which has been dated in this study, and late, dyke-like

248 intrusions up to $2 \mathrm{~km}$ long of unfoliated microgranite. One of the most distinctive of the

249 late phase intrusions is the ring-like Tampoketsa massif in the southern part of the

250 Anaboriana-Manampotsy Belt. It forms a pronounced circular topographic feature that

251 attains an altitude of nearly $1400 \mathrm{~m}$ and appears to be a primary igneous feature, not due

252 to late domal folding. The Tampoketsa intrusion is extremely magnetic compared to the

253 surrounding rocks and forms a major positive aeromagnetic anomaly. Summit exposures

254 show the main lithology to be light grey-pink, fine- to medium-grained, biotite-

255 hornblende alkaline microgranite with a variably-developed foliation. It is included with

256 the Maevarano Suite on the basis of lithological, petrographical and fabric similarities,

257 but it has not been dated.

258 Late minor veins, sheets and irregular intrusions are not common but do occur

259 locally. They include pegmatitic and aplitic granite intrusions, which tend to occur in

260 small swarms, and larger bodies of fine- to medium-grained granite. These are considered

261 to represent the youngest part of the late phase of the Maevarano Suite.

263 4. Petrography

$264 \quad 4.1$ Early phase

265 The early phase intrusions are the most mafic parts of the Maevarano Suite, 266 ranging from granodiorites, monzonites and monzodiorites, to diorites and gabbros. All 267 are medium- to coarse-grained. In the granitoids, plagioclase (20-30\%) dominates over 268 K-feldspar (up to $10 \%$ ). Up to $25 \%$ quartz is present, and mafic minerals include biotite, 
clinopyroxene and amphibole in varying amounts. Minerals are typically allotriomorphic 270 and show a strong preferred orientation.

271 Samples of gabbro consist of plagioclase ( $30-40 \%)$, clinopyroxene (25-35\%), 272 amphibole (10-20\%), biotite (5-10\%), and opaque minerals (up to 5\%) along with 273 accessory titanite and apatite. Up to 5\% quartz occurs in some samples. While the 274 hydrous minerals (amphibole and mica) are clearly of secondary origin, primary sub275 ophitic textures are locally preserved.

$276 \quad 4.2$ Main phase

277 Typical porphyritic granite samples are coarse-grained hypersolvus granites, with 278 microperthitic potassium feldspar phenocrysts up to $2.5 \mathrm{~cm}$ in size, though averaging 1.5 $279 \mathrm{~cm}$. Overgrowths of plagioclase on the potassium feldspar phenocrysts are present in a 280 few samples. The modal mineralogy comprises quartz ( 20-30\%), poikilitic K-feldspar 281 (microperthitic microcline, $\sim 30-40 \%$ ), plagioclase ( $15-20 \%$ ), greenish-brown amphibole 282 ( 10\%), brown biotite (5-10\%), clinopyroxene relics (up to $5 \%$ ) and accessory opaque 283 mineral phases (up to 3\%), apatite, zircon \pm allanite, with epidote, chlorite and muscovite 284 as minor alteration products. Myrmekitic quartz-feldspar intergrowths are common.

285 Feldspars are generally fresh, showing only limited amounts of alteration, and textures 286 are most commonly granoblastic. The charnockitic phases have broadly similar 287 mineralogy to the porphyritic granites, but with 5-20\% orthopyroxene. In most samples, 288 the orthopyroxene is highly altered, and largely replaced by amphibole.

2894.3 Late phase

290 Late phase granitoids are predominantly medium-grained, with allotriomorphic

291 textures, and are commonly quite fresh, although feldspars are locally sericitised. K-

292 feldspar (microperthitic microcline, $\sim 25-40 \%$ ) predominates over plagioclase (10-20\%)

293 with up to 30\% quartz. Mafic minerals are amphibole and biotite, with similar accessories 294 to the granitoids of the main phase. 
Four samples belonging to the Maevarano Suite were selected for $\mathrm{U}-\mathrm{Pb}$ zircon

298 geochronology. All the samples are from plutons emplaced into the Anaboriana-

299 Manampotsy Belt, where the Maevarano Suite intrusions are at their most voluminous.

300 Location information for the samples is given as grid references using the Laborde grid,

301 and localities are shown on Figs. 2 and 3. The zircon data are given in electronic

302 supplemental data tables A-D. The samples were chosen from older and younger phases,

303 on the basis of field relations, in order to bracket the emplacement age of the entire suite.

304 The charnockite phase from the Marojejy area in the Bemarivo Belt has been dated at 521

$305 \pm 4 \mathrm{Ma}$ (Buchwaldt et al., 2003), so was not reinvestigated in this study. Three of our

306 samples were taken from the Maevarano River valley, where the field relationships

307 between the phases are clear. From this region we collected samples of: the early phase

308 (foliated quartz monzodiorite), which occurs as raft-like bodies in the porphyritic granite;

309 a foliated late phase leucogranite sheet cutting the porphyritic granite; and a late phase

310 monzonite pluton which intrudes both leuco- and porphyritic granite. The fourth sample

311 was collected from further south, where late veins and irregular bodies of granite cut

312 migmatitic gneisses of the Anaboriana-Manampotsy Belt.

\section{$313 \quad 5.1$ Methodology}

314 Zircons were separated from large, fresh rock samples using standard crushing,

315 washing, heavy liquid separation (LST and MI liquids) and magnetic separation (Frantz

316 Isodynamic Separator) techniques, followed by hand-picking under a binocular

317 microscope. The grains were mounted in epoxy, and polished mid-section to expose their

318 centre. Mounts were imaged using transmitted and reflected optical microscopy as well as

319 by cathodoluminescence (CL) on a Scanning Electron Microscope.

320 The zircons were dated using the Sensitive High Resolution Ion Microprobe

321 (SHRIMP) at Curtin University of Technology, Perth, Western Australia. Methodologies

322 for SHRIMP analyses followed those described in De Waele and Pisarevsky (2008).

323 Common $\mathrm{Pb}$ correction was carried out, using measured ${ }^{204} \mathrm{~Pb}$, and applying a common

$324 \mathrm{~Pb}$ composition appropriate for the age of the zircon, following Stacey and Kramers

325 (1975). All pooled ages are reported at 95\% confidence levels, while single data are

326 reported at $1 \sigma$ confidence level. SHRIMP data were reduced using the Squid plug-in for 
327 Excel (Ludwig, 2001a), and plotted and interpreted using the Isoplot plug-in for Excel

328 (Ludwig, 2001b). All data are plotted uncorrected for non-radiogenic $\mathrm{Pb}$.

Sample BT/07/12 is a foliated quartz monzodiorite of the early phase, taken from large river outcrops and pavements in the Maevarano River near Ambodirafia (Fig. 3).

332 The sampled lithology is medium- to coarse-grained, fresh, grey, hornblende-biotite

333 quartz monzodiorite, with a strong, sub-vertical foliation trending SSE-NNW. It is fairly

334 homogeneous, but locally has a weak layering defined by variations in grain size and 335 mineralogy, and most notably by layers with more or less K-feldspar. The rocks are 336 weakly migmatitic, with $<5 \%$ layer-parallel leucocratic veins. These foliated quartz 337 monzodiorites to granodiorites occur as large enclaves, up to several hundreds of metres 338 wide, surrounded and veined by very coarse-grained, pink, porphyritic granite of the main 339 phase of the Maevarano Suite.

340 Zircons from sample BT/07/12 range in size from 50 to $200 \mu \mathrm{m}$ and have length 341 to width ratios between 1:1 and 3:1. The crystals are rounded to subrounded and appear 342 colourless to pale pink in transmitted light. Most zircons contain some cracks, but have 343 only very small amounts of inclusions. CL images reveal dark CL-response, and faint 344 parallel zoning patterns (Fig. 5a-b). Some zircons appear to be overgrown by large high345 response domains that show no zoning. Large invasive zones of homogenisation, 346 recognised in many zircons, are interpreted to record solid-state recrystallisation.

$347 \quad 16$ analyses were conducted on this sample and indicate low $f_{206}$ values up to $348 \quad 1.14 \%$ (Table A). $\mathrm{U}$ and Th are in the range 71-379 and 91-495 ppm respectively, with 349 the exception of analysis 6 (1196 and $2066 \mathrm{ppm}$ ). Th/U ratios are between 0.29 and 2.82, 350 extending well beyond the typical ratios expected for magmatic zircon $(0.5<\mathrm{Th} / \mathrm{U}<1.0)$, 351 possibly due to some $\mathrm{Th} / \mathrm{U}$ fractionation during solid-state recrystallisation.

352 Apart from three data points that record the highest common lead $\left(\mathrm{Pb}_{\mathrm{c}}\right)$ values, the 353 data on cores define a concordant cluster (Fig. 6). The seven most concordant analyses 354 yield a concordia age of $531 \pm 5 \mathrm{Ma}$ (MSWD of concordance $=2.0$ ). The relatively high 355 MSWD of concordance indicates some scatter in the dataset, but the age represents the 356 best estimate for crystallisation of zircon cores in sample BT/07/12. Six analyses 
357 conducted on unzoned high-CL rims, although discordant due to incorrect correction for $358 \mathrm{~Pb}_{\mathrm{c}}$, seem to record slightly younger crystallisation ages around $\sim 520 \mathrm{Ma}$. Although this

359 age cannot be fully resolved based on the data obtained, it does suggest crystallisation of

360 these rims immediately after the emplacement of the granite, perhaps from late-stage

361 fluids associated with the intrusion of the main phase granites.

3625.3 Sample BT/07/22 [grid ref. 610788 1269827]

363 Sample BT/07/22 is from a small elliptical, late phase pluton near the Maevarano

364 River, where tor-like outcrops are characterised by a curious "fluted", pot-holed

365 appearance. This pluton intrudes the main, porphyritic phase of the Maevarano Suite, and

366 is foliated within a few tens of metres of its margins, but elsewhere essentially unfoliated.

367 The sample is a homogeneous, slightly foliated, pinkish-grey, medium- to coarse-grained,

368 biotite-amphibole monzogranite. Sparse K-feldspars, up to $8 \mathrm{~mm}$ in size, are largely

369 perthitic. The rock contains a few discrete, spherical microdiorite xenoliths which were

370 carefully excluded from the analysed sample.

371 Zircon grains range in size from 100 to $300 \mu \mathrm{m}$ and have aspect ratios between

372 2:1 and 4:1 (Fig. 5c-d). The crystals are clear, colourless to pale pink, and are commonly

373 cracked. CL imaging indicates single sector zoning, with alternating dark- and light-CL

374 zones (Fig. 5c-d). Zoning patterns and the high aspect ratios of most crystals suggest a

375 magmatic origin.

$376 \quad 16$ analyses were conducted and give $f_{206}$ values between 0 and 2.66 (Table B). $U$

377 and Th values are low, between 26-128 and 46-239 ppm respectively, leading to high

378 proportions of apparent $\mathrm{Pb}_{\mathrm{c}}$ based on very low counts on ${ }^{204} \mathrm{~Pb}$. None of the analyses

379 recorded more than 1 count over 10 second intervals, similar to measurements on

380 background, and this is taken to indicate extremely low $\mathrm{Pb}_{\mathrm{c}}$. Uncorrected data plot on

381 concordia and define a concordia age of $522 \pm 6 \mathrm{Ma}$ (MSWD of concordance $=0.50$, Fig.

382 6), which we take to reflect the emplacement age of the monzogranite. One younger

383 analysis could represent crystallisation of zircon at ca. $464 \pm 10 \mathrm{Ma}$ (analysis 8), but more

384 likely represents a zircon that lost $\mathrm{Pb}$.

385 5.4 Sample BT/07/25 [grid ref. 606786 1267524] 
Sample BT/07/25 is from a late phase intrusion of the Maevarano Suite which

387 largely comprises fine- to medium-grained, foliated, biotite-bearing microgranite, and

388 which intrudes the porphyritic granite. The foliation in rocks of this microgranite is

389 variable, but commonly quite strong, and defined by small variations in mineralogy and

390 grain size. A slightly coarser-grained quartz-feldspar facies forms discontinuous layers

391 and blebs, defining a weak, diffuse layering. No mafic enclaves, blebs or schlieren have

392 been observed - the rocks are typically homogeneous at the outcrop scale. The sample is

393 a light grey, medium- to fine-grained, pinkish microgranite with a weak foliation formed

394 by alignment of mafic aggregates.

395 Zircon crystals are between 100 and $250 \mu \mathrm{m}$ in size, and have aspect ratios

396 between 2:1 and 5:1 (Fig. 5e-f). The crystals are sub- to euhedral in shape, and have well-

397 defined crystal terminations. The crystals are virtually free of inclusions and cracks, and

398 vary between colourless and pale pink. CL images show concentric and parallel zones

399 that suggest a magmatic origin (Fig. 5e-f). A small number of larger zircons appear to

400 have a homogenous inner dark-CL core, overgrown by a medium-CL homogenous rim.

$401 \quad 15$ analyses were conducted on 15 zoned crystals and indicated low contents of

$402 \mathrm{~Pb}_{\mathrm{c}}$ with $\mathrm{f}_{206}$ between 0 and $1.09 \%$, corresponding to less than one count on ${ }^{204} \mathrm{~Pb}$ every

403 ten seconds (Table C). U and Th contents are in the range 161-734 and 116-1936 ppm

404 respectively, giving $\mathrm{Th} / \mathrm{U}$ ratios between 0.57 and 2.85 .

405 The data plot in a broad cluster on concordia, and the nine most concordant points

406 (after correction for non-radiogenic $\mathrm{Pb}$ ) correspond to a concordia age of $527 \pm 5 \mathrm{Ma}$

407 (MSWD of concordance=0.005), which we take to represent the best age estimate for the

408 emplacement of the microgranite (Fig. 6). The data points that plot slightly away from

409 this concordant cluster correspond to analyses that either recorded higher counts on ${ }^{204} \mathrm{~Pb}$,

410 or some noise resulting in background counts in excess of counts on ${ }^{204} \mathrm{~Pb}$ (but always

411 less than 1 count every 10 seconds). One analysis (15) recorded a concordant ${ }^{206} \mathrm{~Pb} /{ }^{238} \mathrm{U}$

412 age of $541 \pm 8 \mathrm{Ma}$, and may represent a slightly older xenocrystic component in the

413 sample.

4145.5 Sample RK7248A [grid ref. 632500 1175988] 
416 Belt (Fig. 2), with numerous rock pavements of agmatitic gneiss with a blocky grey

417 gneiss palaeosome surrounded by granitic leucosome, and cut by discrete veins and

418 irregular bodies of granite. The analysed sample was taken from one of the late granite

419 bodies.

420 Zircon crystals range in size from 100 to $200 \mu \mathrm{m}$ and have aspect ratios between

$4212: 1$ and 5:1. The crystals are sub- to euhedral with well-developed terminations,

422 colourless to pale pink, with very few inclusions and virtually no cracks. CL images

423 reveal broad parallel or concentric zoning patterns consistent with magmatic

424 crystallisation (Fig. 5g-h). Several zircon grains are overgrown by narrow high-CL

425 unzoned rims, possibly related to a thermal episode that led to neocrystallisation of low-U

426 rims.

21 analyses yielded $f_{206}$ values between 0 and $0.96 \%$. $U$ and $T h$ are in the ranges

428 104-495 ppm and 53-217 ppm respectively, giving $\mathrm{Th} / \mathrm{U}$ ratios between 0.25 and 1.12,

429 largely within the range expected for magmatic zircon (Table D). The data define a broad

430 cluster around concordia with weighted mean ${ }^{206} \mathrm{~Pb} /{ }^{238} \mathrm{U}$ age of $532 \pm 6 \mathrm{Ma}(\mathrm{MSWD}=5.4)$

431 (Fig. 6). The high MSWD value for this calculation indicates significant scatter of

$432{ }^{206} \mathrm{~Pb} /{ }^{238} \mathrm{U}$ ratios, interpreted to reflect some Pb-loss in the zircons. Using only concordant

433 data, a concordia age of $537 \pm 5 \mathrm{Ma}(\mathrm{MSWD}=0.35)$ can be calculated, which is

434 interpreted as the best estimate for the age of crystallisation of zircon in the sample. High

435 CL rims and magmatically zoned core domains provide similar ages, and this may

436 indicate that emplacement of the granitic protolith took place during a thermal event that

437 induced migmatisation and fluid mobility in the rock.

438 In summary, the four analysed samples show a narrow spread of emplacement

439 ages from $537 \pm 5$ to $522 \pm 6 \mathrm{Ma}$. The younger end of this range is consistent with the

440 emplacement of the Marojejy charnockite in the southern Bemarivo Belt at $520.9 \pm 4.2$

441 Ma (Buchwaldt et al., 2003) and in keeping with the age ranges of metamorphism in the

442 same area (Jöns et al., 2006, 2009). Very few older, inherited zircons were found,

443 suggesting that these magmas did not undergo substantial crustal contamination. 


\section{Geochemistry}

44630 whole-rock samples from representative Maevarano Suite intrusions and

447 phases have been analysed for major, trace and rare earth elements. Fresh rock samples

448 selected for geochemistry were crushed and milled in agate at the DMG Laboratory of the

449 Ministry of Energy and Mines in Antananarivo, and analysed at ACTLABS, Canada (by

450 their Code 4 Lithoresearch package). Major oxides and some trace elements were

451 analysed by Li-metaborate / tetraborate fusion with an ICP analysis, and these sample

452 solutions were further diluted and spiked for ICP-MS analysis. The samples were run for

453 major oxides and selected trace elements on a combination simultaneous/sequential

454 Thermo Jarrell-Ash ENVIRO II ICP or a Spectro Cirros ICP, and for other trace elements

455 on a Perkin Elmer SCIEX ELAN 6000 or 6100 ICP-MS. The data are given in Table 1;

456 details of repeat analyses on standards are presented as supplemental data in Table E..

457 The majority of samples (20) are granitoid rocks, including porphyritic granites

458 and charnockites, of the main granite-charnockite phase of the Maevarano Suite. Just one

459 (dated) granitoid sample is from the early phase, and four samples are gabbros that are

460 also considered to belong to the early phase. Five samples are from the late phase, and

461 include the dated monzogranite and leucogranite, along with the Tampoketsa alkaline 462 granite.

463 The analysed samples show a wide range in $\mathrm{SiO}_{2}$ content, from 45 to $78 \mathrm{wt} \%$, the 464 gabbros having $<55 \mathrm{wt} \% \mathrm{SiO}_{2}$ (Fig. 7). The majority of samples are low in $\mathrm{MgO}(<3 \%)$

465 and show a negative correlation with $\mathrm{SiO}_{2}$ (Fig. 7a), although the early phase samples

466 (gabbros and foliated quartz monzodiorite) have notably higher $\mathrm{MgO}(>3.0 \%)$ than

467 granitoid samples with similar $\mathrm{SiO}_{2}$. As would be expected, $\mathrm{Fe}_{2} \mathrm{O}_{3}$ shows a strong

468 negative correlation with $\mathrm{SiO}_{2}$ (Fig. 7b), with the highest $\mathrm{Fe}_{2} \mathrm{O}_{3}$ contents in the gabbros

$469(>10 \%)$ although some charnockites are also $\mathrm{Fe}_{2} \mathrm{O}_{3}$-rich. All granitoid samples are high

470 in $\mathrm{K}_{2} \mathrm{O}\left(>3.5 \%\right.$ ) whereas gabbro samples have $\mathrm{K}_{2} \mathrm{O}<3.5 \%$ (Fig. 7c), and there is no

471 apparent correlation between $\mathrm{K}_{2} \mathrm{O}$ and $\mathrm{SiO}_{2}$ (Fig. 7c); this suggests buffering by a K-

472 bearing phase such as amphibole, phlogopite or K-feldspar during evolution of the

473 magmas (Williams et al., 2004). $\mathrm{K}_{2} \mathrm{O} / \mathrm{Na}_{2} \mathrm{O}$ is $>1$ in most samples, again with the

474 exception of the four gabbro samples which have $\mathrm{K}_{2} \mathrm{O} / \mathrm{Na}_{2} \mathrm{O}<1$. In the Total Alkalis vs 
475 Silica (TAS) plot (Fig. 7d), most of the samples are alkalic under the classification of 476 Miyashiro (1974). This plot is most appropriate for volcanic rocks, and only provides a 477 crude method of classifying plutonic rocks. However, it is notable that, despite high 478 modal contents of K-feldspar, very few Maevarano Suite samples actually have the bulk 479 composition of true granite; many fall in the broad syenite and syeno-diorite fields, which 480 also encompass monzonitic compositions. The analysed samples are largely 481 metaluminous (molar $\mathrm{A} / \mathrm{CNK}<1$ ) (Fig. 8a), although the most $\mathrm{SiO}_{2}$ rich samples are 482 weakly peraluminous, suggesting the possibility of some crustal contamination of these 483 magmas.

484 In magmatic suites, such as the Maevarano Suite, that do not appear to have 485 suffered extensive post-crystallisation alteration, it is common to attempt to discriminate 486 the tectonic setting of granitoids using discrimination diagrams such as those of Pearce et 487 al. (1984). Granitoid samples from the Maevarano Suite are plotted on the ( $\mathrm{Y}+\mathrm{Nb}) \mathrm{vs} \mathrm{Rb}$ 488 plot of Pearce et al. (1984) (Fig. 8b) and although most plot in the within-plate granite 489 field, there is an overlap into the volcanic arc and syn-collisional granite fields. This 490 spread across fields is common in post-collisional granites (Pearce, 1996) and the 491 Maevarano Suite shows the same spread as other post-collisional granitoids from the 492 EAO (e.g. Roland, 2004; Küster and Harms, 1998). On the Ga/Al vs. Zr plot of Whalen 493 et al. (1987) the Maevarano Suite granitoids plot in the field of A-type granites (Fig. 8c), 494 as do other EAO post-collisional granites (Roland, 2004; Küster and Harms, 1998). In the 495 A-type granite classification of Eby $(1990,1992)$ the Maevarano Suite granitoids spread 496 across the $A_{1}$ and $A_{2}$ fields (Fig. 8d). Post-collisional granitoids would normally be 497 expected to fall in the $\mathrm{A}_{2}$ field, which indicates magmas that may have been derived by 498 re-melting of crust. In contrast, magmas in the $A_{1}$ field are more likely to have been 499 derived from mantle sources (Eby, 1992).

500 Samples from the early phase show many consistent trace element characteristics 501 (Fig. 9a). Most are relatively enriched in $\mathrm{Ba}, \mathrm{K}$, and the LREE, with negative $\mathrm{Ta}-\mathrm{Nb}$ 502 anomalies and depletion in the HREE relative to the LREE $\left(\mathrm{La}_{\mathrm{N}} / \mathrm{Yb}_{\mathrm{N}}\right.$ typically $\left.>10\right)$. One 503 analysed sample, KGM48, lacks a Nb-Ta anomaly and has a relatively flat slope from the 504 LREE to the HREE, and it is possible that this intrusion was derived a different source to 505 the other Maevarano Suite magmas. Sample 497-JM-07 shows positive Sr, Ti and Eu 
anomalies, suggesting that its bulk composition has been modified by crystal accumulation (plagioclase and ilmenite) and cannot be used to approximate a magmatic composition.

509 The more evolved samples of the main granite-charnockite phase show higher 510 contents of some of the Large Ion Lithophile Elements (LILE) (especially Rb, Th and $\mathrm{K}$ ) 511 than the mafic samples of the early phase (Fig. 9b), but have many similar characteristics 512 including negative $\mathrm{Nb}$-Ta anomalies and fractionated REE patterns $\left(\mathrm{La}_{\mathrm{N}} / \mathrm{Yb}_{\mathrm{N}}>10\right)$.

513 Strong negative Sr and Ti anomalies (and in one case a weak Eu anomaly) in the main 514 phase samples indicate that plagioclase and a Ti-rich mineral such as titanite or ilmenite 515 were fractionated as the magmas evolved.

516 Samples from the late magmatic phases can be divided into two groups on the 517 basis of their trace element patterns (Fig. 9c). Monzogranites and leucogranites of the 518 Maevarano River area have similar trace element patterns to the main phase granites, 519 though strong Eu and $\mathrm{Sr}$ negative anomalies indicate that these magmas are highly 520 evolved. Two samples from the Tampoketsa granite have pronounced negative $\mathrm{Nb}-\mathrm{Ta}$ 521 anomalies and very low contents of the $\operatorname{HREE}\left(\mathrm{La}_{N} / \mathrm{Yb}_{\mathrm{N}}>80\right)$. These differences may 522 indicate a different source for this unusual intrusion. Low contents of HREE commonly 523 indicate the presence of garnet in the source of the magmas, and so it is possible that the 524 parental magma of the Tampoketsa granite was derived from greater depth than those of 525 other parts of the Maevarano Suite.

526 The similarity in geochemistry between most phases of the Maevarano Suite 527 supports the assignation of these intrusions to a single magmatic suite. These intrusions 528 show many of the typical features that have been recognised in post-collisional granitoids 529 of the EAO (Küster and Harms, 1998; Nédelec et al., 1995; Roland, 2004), including: 530 high contents of the LILE, especially $\mathrm{K}$; negative $\mathrm{Nb}$-Ta anomalies; and enrichment of 531 the LREE over the HREE. Perhaps the single most distinctive feature of these and other 532 post-collisional granitoids is that they plot in the A-type granite fields on discrimination 533 diagrams, yet have strong negative $\mathrm{Nb}$-Ta anomalies which would not be expected in 534 granitoids formed in an intracontinental rift setting (Whalen et al., 1987). 
537 The Maevarano Suite of northern Madagascar comprises three recognisable 538 phases of intrusion, of which the second, main phase was the most voluminous. Both 539 field and geochronological evidence show that the suite was emplaced shortly after the 540 main deformation associated with the Malagasy orogeny - the last orogenic event to 541 affect the East African Orogen in Madagascar (Collins and Pisarevsky, 2005; Collins, 542 2006). In the field, some exposures show that the intrusive rocks, particularly of the late 543 phase, cut the main foliation in their country rocks. However, the contacts of granitoids of 544 the main phase are commonly broadly parallel to the regional fabrics and the granites are 545 themselves foliated at pluton margins, but unfoliated in their cores. Components of the 546 early phase tend to be pervasively foliated and form elongate bodies that are parallel to 547 the foliation in the host rocks. This indicates that the Maevarano Suite magmatism largely 548 post-dated the main crustal thickening event, but that the early phase intrusions were 549 emplaced during its waning stages.

550 In its type area, the Maevarano Suite is associated with a number of ductile shear 551 zones. This is a common association for post-collisional granites in the EAO, and in some 552 areas the later deformation on the shear zones has been associated with orogenic collapse 553 (Jacobs and Thomas, 2004; Jacobs et al., 2008; Bingen et al., 2009; Grégoire et al., 2009;

554 Viola et al., 2008). Although field evidence for this is limited in northern Madagascar, we 555 can use these analogies to tentatively suggest that the earliest Maevarano Suite magmas 556 were emplaced at the end of the collisional event, but that voluminous main phase 557 magmatism was associated with extensional collapse of the orogen, with extensional 558 shear zones providing the pathways for magma ascent.

559 The observed field relationships are consistent with the geochronology; high560 grade metamorphism in north Madagascar peaked at ca. 560 - 530 Ma (Jöns et al., 2006, 561 2009), and our work has shown that the earlier, foliated phases of the Maevarano Suite 562 were emplaced at ca. 537 - $531 \mathrm{Ma}$, with magmatism continuing until $520 \mathrm{Ma}$. A similar 563 pattern is recognised in central Madagascar, where metamorphism on the Angavo Shear 564 Zone occurred at ca. $550 \mathrm{Ma}$ (Grégoire et al., 2009) followed by magmatism at ca. 550 565530 Ma (Tucker et al., 1999; Kröner et al., 1999, 2000; Meert et al., 2001). 
Petrography and geochemical analyses demonstrate that the Maevarano Suite intrusions share many features - such as LILE enrichment, negative $\mathrm{Nb}$-Ta anomalies, and LREE enrichment over the HREE - with other post-collisional granitoids along the length of the EAO. A number of apparent contradictions characterise these postcollisional granitoids: for instance, charnockites typically indicate water-undersaturated magmas, yet they are associated with amphibole-bearing granites that are likely to have formed from hydrous magmas. Similarly, discrimination diagrams indicate that these are A-type granites, yet they have the strong $\mathrm{Nb}$-Ta negative anomaly commonly found in arc settings. Such $\mathrm{Nb}-\mathrm{Ta}$ anomalies could be partly caused by contamination with local crustal material, but it is notable that the anomalies are present even in the most mafic magmas that are likely to be relatively uncontaminated. The lack of older xenocrystic zircons in the dated samples also provides an argument against substantial crustal contamination of the magmas.

The consistency of many main geochemical features of post-collisional intrusions along the EAO suggests the likelihood of a common source for the majority of these magmas. The granitoids are largely metaluminous, rather than peraluminous, indicating that they were not generated solely by the melting of local crustal material, although the

583 more silica-rich magmas are likely to have been affected by some crustal contamination.

584 Recent studies have proposed that the source of post-collisional magmas elsewhere in the 585 EAO was in the mafic lower crust (e.g. Jacobs et al., 2008); but the lower crust is likely 586 to be depleted in the LILE rather than enriched (Pearce, 1996), and so does not represent 587 a feasible source for the K-rich Maevarano Suite. A growing consensus (e.g. Pearce, 588 1996; Liégeois et al., 1998; Bonin, 2004) is that the source for K-rich post-collisional 589 magmas is in the sub-continental lithospheric mantle (SCLM), which has been 590 heterogeneously enriched through metasomatism by LILE-enriched fluids derived by 591 dehydration of a subducting slab. Such slab fluids are typically characterised by low Nb592 Ta contents (Fitton, 1995) and thus the enriched SCLM would also have low amounts of 593 these elements. Partial melting of such a source could produce the LILE-enriched, Nb594 Ta- poor magmas of the Maevarano Suite, and we suggest that other post-collisional 595 magmas in the EAO were also derived from metasomatised SCLM. In northern 596 Madagascar, there is abundant evidence for subduction during the Neoproterozoic, prior 
597 to collision of the terranes that make up the island (e.g., arc-like magmas; Thomas et al., 598 2009), and enrichment of the SCLM could have occurred at this time. In the north of the 599 EAO, alkaline parts of the post-collisional granitoid suite have similarly been attributed

600 to a lithospheric mantle source that was metasomatised during Neoproterozoic subduction 601 (Be’eri-Shlevin et al., 2009b).

602 The transition from crustal shortening to extension in many orogenic belts, 603 including the EAO, has been explained in terms of delamination of part, or all, of the sub604 continental lithospheric mantle (Houseman and Mackenzie, 1981; Black and Liégeois, 605 1993; Jacobs et al., 2008). Such delamination allows hot asthenospheric material to well 606 up, heating the upper part of the lithospheric mantle and promoting melting (Schott and 607 Schmeling, 1998). Bonin (2004) proposed a model for collisional to post-collisional 608 magmatism that commences with lithospheric stacking, producing peraluminous magmas 609 derived by melting of continental crust which mingle with small-degree potassic melts 610 from the SCLM. This is followed by slab break-off and lithospheric delamination, 611 removing part of the lithospheric mantle keel and melting the upper part of the SCLM to 612 produce medium- to high-K magmas. Finally, this model (Bonin, 2004) suggests that 613 over a period of millions of years the SCLM thickens by cooling and underplating of 614 deeper material, and alkaline magmas of within-plate type are derived from deeper levels. 615 The majority of the Maevarano Suite magmas can be related to the slab break-off/ 616 lithospheric delamination stage of this model. However, the youngest Tampoketsa granite 617 may have been formed by melting of deeper SCLM and could represent the evolution to a 618 true within-plate setting; it is possible that it is rather younger than the rest of the 619 Maevarano Suite.

620 Within northern Madagascar, the Maevarano Suite intrusions are abundant within 621 some crustal units (the Anaboriana-Manampotsy and Bemarivo belts, and parts of the 622 Antananarivo Craton) but are absent in others (the Antongil Craton). Two explanations 623 can be postulated: 1) a suitable source was not present beneath the Antongil Craton; 2) 624 structural controls led to the emplacement of magmas only in certain areas.

625 Evidence to support the first explanation comes from study of the Neoproterozoic 626 history of the terranes of northern Madagascar. The Bemarivo Belt and the Antananarivo 
627 Craton both contain abundant Neoproterozoic subduction-related magmatic suites (820-

628700 Ma; Handke et al., 1999; Tucker et al., 1999; Kröner et al., 2000; Thomas et al., 629 2009), which provide evidence for a subduction event prior to collision that could have 630 enriched the SCLM. The country rocks of the Anaboriana-Manampotsy Belt are entirely 631 Neoproterozoic (BGS-USGS-GLW, 2008) and may represent an arc sequence preserved 632 within the suture zone between continental fragments. In contrast, there is no evidence of 633 Neoproterozoic magmatism within the Antongil Craton (BGS-USGS-GLW, 2008). We 634 therefore postulate that the SCLM beneath the Antongil Craton was not enriched by 635 subduction-related fluids prior to continental collision, and thus was less hydrous and 636 more viscous than the SCLM beneath other parts of northern Madagascar. This unaltered 637 lithospheric mantle may simply not have delaminated (e.g. Elkins-Tanton, 2005), or may 638 have lacked fusible material that could be melted to produce post-collisional magmas.

639 Evidence for the second explanation comes from the common association of 640 Maevarano Suite granitoids with major shear zones, which seem to be focused 641 particularly along terrane boundaries. As suggested above, the Antongil Craton may have 642 had a thicker, more viscous lithospheric root than the surrounding mobile belts, and so 643 may have behaved in a rigid fashion, leading to the development of shear zones along the 644 craton margins during collapse of the orogen (cf. Black and Liégeois, 1993). Magmas 645 were then emplaced along these shear zones.

646 It is likely that both these possible explanations are valid, and indeed linked.

647 Areas which had undergone Neoproterozoic subduction had hydrous, relatively dense 648 metasomatised SCLM that was a candidate both for delamination and for partial melting. 649 In contrast, areas that were unaffected by Neoproterozoic subduction were relatively 650 rigid, with anhydrous lithospheric roots that were not highly susceptible to either 651 delamination or melting. Shear zones, which developed at the boundaries between these 652 two types of terranes, focused the post-collisional magmas.

\section{8. Conclusions}


657 Ma during the waning stages of the East African Orogen. Plutons of the Maevarano Suite

658 are commonly associated with ductile shear zones, which may have developed during

659 extensional collapse of the orogen. Distinctive geochemical features of these intrusions,

660 including LILE enrichment, negative $\mathrm{Nb}$-Ta anomalies, and LREE enrichment over

661 HREE, point to a source in metasomatised sub-continental lithospheric mantle.

662 Maevarano Suite plutons are situated in areas where there is evidence for Neoproterozoic

663 subduction, but absent from areas that were not reworked at that time. We therefore

664 propose that the SCLM was metasomatised during Neoproterozoic subduction events and

665 subsequently melted during lithospheric delamination; areas such as the Antongil Craton

666 whose SCLM was not metasomatised, either did not delaminate, or were less susceptible

667 to partial melting. The magmas were then emplaced along crustal-scale shear zones.

668 Many of the conclusions drawn from this work can be applied along the length of

669 the EAO, where similar post-collisional plutons are common. We suggest that the source

670 for most of these post-collisional magmas is likely to lie in the SCLM, and that abundant

671 post-collisional plutons will be focused in areas where that SCLM was metasomatised

672 through Proterozoic subduction.

674 Acknowledgments

675 The authors would like to thank the many BGS, USGS and Malagasy colleagues who

676 were involved in fieldwork in Madagascar during 2005-2007. Martin Gillespie is thanked

677 for constructive comments on an earlier version, and Alan Collins and Joachim Jacobs

678 are thanked for their detailed and thoughtful reviews, all of which greatly improved the

679 manuscript. Editorial comments by Nelson Eby were also much appreciated. This paper

680 is published with the permission of the Executive Director of the British Geological

681 Survey (NERC). Age data in this paper were obtained at the Perth Consortium SHRIMP

682 facilities at the Curtin University of Technology, which are funded by the Australian

683 Research Council.

684

685 References 
Be'eri-Shlevin, Y., Katzir, Y., Whitehouse, M, 2009a. Post-collisional tectonomagmatic evolution in the northern Arabian-Nubian Shield: time constraints from ion-probe $\mathrm{U}-\mathrm{Pb}$ dating of zircon. Journal of the Geological Society of London 166, 71-85.

Be'eri-Shlevin, Y., Katzir, Y., Valley, J.W., 2009b. Crustal evolution and recycling in a juvenile continent: Oxygen isotope ratio of zircon in the northern Arabian-Nubian Shield. Lithos 107, 169-184

Besairie, H., 1964. Madagascar carte géologique. Service Géolographique à Madagascar, Tananarive.

Besairie, H., 1971. Carte Géologique à 1/2000000 et notice explicative, No. 189. Bureau de Géologique Madagascar, Tananarive.

BGS-USGS-GLW, 2008. Revision de la cartographie géologique et minière des zones Nord et Centre de Madagascar, Republique de Madagascar Ministère de L'Energie et des Mines, Antananarivo.

Bingen, B., Jacobs, J., Viola, G., Henderson, I. H. C., Skar, Ø., Boyd, R., Thomas, R.J., Solli, A., Key, R.M., Daudi, E.X.F., 2009. Geochronology of the Precambrian crust in the Mozambique belt in NE Mozambique, and implications for Gondwana assembly. Precambrian Research 170, 231-255.

Black, R., Liégeois, J.P., 1993. Cratons, mobile belts, alkaline rocks and continental lithospheric mantle; the Pan-African testimony. Journal of the Geological Society of London 150, 89-98.

Bonin, B., 2004. Do coeval mafic and felsic magmas in post-collisional to within-plate regimes necessarily imply two contrasting, mantle and crustal, sources? A review. Lithos 78, 1-24.

Buchwaldt, R., Tucker, R.D., Dymek, R.F., 2003. Geothermobarometry and U-Pb Geochronology of metapelitic granulites and pelitic migmatites from the Lokoho region, Northern Madagascar. American Mineralogist 88, 1753-1768.

Collins, A.S., Windley, B.F., 2002. Tectonic evolution of central and northern Madagascar and its place in the final assembly of Gondwana. Journal of Geology $110,325-339$.

Collins, A.S., Fitzsimons, I.C.W., Hulscher, B., Razakamanana, T., 2003a. Structure of the eastern margin of the East African Orogen in central Madagascar. Precambrian Research 123, 111-133.

Collins, A.S., Johnson, S., Fitzsimons, I.C.W., Powell, C.M., Hulscher, B., Abello, J. and Razakamanana, T., 2003b. Neoproterozoic deformation in central Madagascar: a structural section through part of the East African Orogen. In: Yoshida, M., Windley, B., and Dasgupta, S. (Eds.) Proterozoic East Gondwana: Supercontinent Assembly and Breakup. Special Publication of the Geological Society, London 206, 363-379.

Collins, A.S., Pisarevsky, S.A., 2005. Amalgamating eastern Gondwana: The evolution of the Circum-Indian Orogens. Earth Science Reviews 71, 229-270.

Collins, A.S., 2006. Madagascar and the amalgamation of Central Gondwana. Gondwana Research 9, 3-16.

Cox, R., Armstrong, R.A., Ashwal, L.D., 1998. Sedimentology, geochronology and provenance of the Proterozoic Itremo Group, central Madagascar, and implications for pre- Gondwana palaeogeography. Journal of the Geological Society $155,1009-1024$. 
De Waele, B., Pisarevsky, S.A. 2008. Geochronology, paleomagnetism and magnetic fabric of metamorphic rocks in the northeast Fraser Belt, Western Australia. Australian Journal of Earth Sciences 55, 605-621.

De Wit, M.J., Bowring, S.A., Ashwal, L.D., Randrianasolo, L.G., Morel, V.P.I., Rambeloson, R.A., 2001. Age and tectonic evolution of Neoproterozoic ductile shear zones in southwestern Madagascar, with implications for Gondwana studies. Tectonics 20, 1-45.

Eby, G.N., 1990. The A-type granitoids: A review of their occurrence and chemical characteristics and speculations on their petrogenesis. Lithos 26, 115-134.

Eby, G.N., 1992. Chemical subdivision of the A-type granitoids: Petrogenetic and tectonic implications. Geology 20, 641-644.

Elkins-Tanton, L.T., 2005. Continental magmatism caused by lithospheric delamination. In: Foulger G.R., Natland J.H., Presnall D.C., Anderson D.L. (Eds.), Plates, Plumes and Paradigms: Geological Society of America Special Paper 388, 449461.

Fitton, J.G., 1995. Coupled molybdenum and niobium depletion in continental basalts. Earth and Planetary Science Letters 136, 715-721.

Gillespie, M.R., Styles, M.T., 1999. Rock Classification Scheme Volume 1, Classification of Igneous Rocks. British Geological Survey, Keyworth, Nottingham.

Gregoire, V., Nédélec, A., Monie, P., Montel, J-M., Ganne, J., Ralison, B., 2009. Structural reworking and heat transfer related to the late Panafrican Angavo shear zone of Madagascar. Tectonophysics 477, 197-216

Handke, M., Tucker, R.D., Ashwal, L.D., 1999. Neoproterozoic continental arc magmatism in west-central Madagascar. Geology 27, 351-354.

Hottin, G., 1972. Madagascar: Représentation schématique du volcanisme, de la tectonique cassante, et des formations précambriennes. Echelle 1:2,000,000 Bureau de Recherches Géologiques et Minières, Limoges, France.

Houseman, G.A., McKenzie, D.P., 1981. Convective instability of a thickened boundary layer and its relevance for the thermal evolution of continental convergent belts. Journal of Geophysical Research 86, 6115-6132.

Jacobs, J., Bingen, B., Thomas, R.J., Bauer, W., Wingate, M.T.D., Feitio, P., 2008. Early Palaeozoic orogenic collapse and voluminous late-tectonic magmatism in Dronning Maud Land and Mozambique: insights into the partially delaminated orogenic root of the East African - Antarctic Orogen. In: Satish-Kumar, M., Motoyoshi, Y., Osanai, Y., Hiroi, Y.and Shiraishi, K. (Eds.) Geodynamic Evolution of East Antarctica: A Key to the East-West Gondwana Connection. Geological Society of London Special Publication 308, 69-90.

Jacobs, J. Thomas, R.J., 2004. Himalayan-type indenter-escape tectonics model for the southern part of the late Neoproterozoic-early Palaeozoic East African-Antarctic orogen. Geology 32, 721-724.

Johnson, S.P., Rivers, T., De Waele, B., 2005. A Review of the Mesoproterozoic to early Palaeozoic magmatic and tectonothermal history of south-central Africa: implications for Rodinia and Gondwana. Journal of the Geological Society of London 162, 433-450.

Jöns, N., Emmel, B., Schenk, V., Razakamanana, T., 2009. From orogenesis to passive 
margin - the cooling history of the Bemarivo Belt (N Madagascar), a multithermochronometer approach. Gondwana Research 16, 72-81.

Jöns, N., Schenk, V., Appel, P., Razakamanana, T., 2006. Two-stage metamorphic evolution of the Bemarivo Belt of northern Madagascar: constraints from reaction textures and in situ monazite dating. Journal of Metamorphic Geology 2006(24), 10.

Kröner, A., Hegner, E., Collins, A.S., Windley, B.F., Brewer, T.S., Razakamanana, T., Pidgeon, R.T., 2000. Age and magmatic history of the Antananarivo Block, central Madagascar, as derived from zircon geochronology and $\mathrm{Nd}$ isotopic systematics. American Journal of Science 300(4), 251-288.

Kröner, A., Windley, B.F., Jaeckel, P., Brewer, T.S., Razakamanana, T., 1999. New zircon ages and regional significance for the evolution of the Pan-African orogen in Madagascar. Journal of the Geological Society, London 156, 1125-1135.

Küster, D., Harms, U., 1998. Post-collisional potassic granitoids from the southern and northwestern parts of the Late Neoproterozoic East African Orogen: a review. Lithos 45, 177-195.

Le Bas, M.J., Le Maitre, R.W., Streckeisen, A., Zanettin, B., 1986. A chemical classification of volcanic rocks based on the total alkali-silica diagram. Journal of Petrology 27, 745-750.

Liégeois, J.P., Navez, J., Hertogen, J., Black, R., 1998. Contrasting origin of postcollisional high-K calc-alkaline and shoshonitic versus alkaline and peralkaline granitoids. The use of sliding normalization. Lithos 45, 1-28.

Ludwig, K.R., 2001a. Squid 1.02: A User's Manual. 2, Berkeley Geochronology Center, Berkeley.

Ludwig, K.R., 2001b. Isoplot/Ex rev. 2.49, Berkeley Geochronology Centre, Berkeley, California.

McDonough, W.F., Sun, S.-s., 1995. The Composition of the Earth. Chemical Geology 120, 223-253.

Meert, J.G., 2003. A synopsis of events related to the assembly of eastern Gondwana. Tectonophysics 362(1-4), 1-40.

Meert, J.G., Nédélec, A., Hall, C., 2003. The stratoid granites of central Madagascar: paleomagnetism and further age constraints on Neoproterozoic deformation. Precambrian Research 120, 101-129.

Meert, J.G., Nédélec, A., Hall, C., Wingate, M.T.D., Rakotondrazafy, M., 2001. Paleomagnetism, geochronology and tectonic implications of the Cambrian-age Carion Granite, central Madagascar. Tectonophysics 340, 1-21.

Miyashiro, A., 1974. Volcanic rock series in island arcs and active continental margins American Journal of Science 274, 321-355.

Möller, A., K., M., Schenk, V., 2000. U-Pb dating of metamorphic minerals: Pan-African metamorphism and prolonged slow cooling of high pressure granulites in Tanzania, East Africa. Precambrian Research 104, 123-145.

Nédélec, A., Ralison, B., Bouchez, J.-L., Gregoire, V., 2000. Structure and metamorphism of the granitic basement around Antananarivo: A key to the PanAfrican history of central Madagascar and its Gondwana connections. Tectonics 19, 997-1020.

Nédélec, A., Stephens, W.E., Fallick, A.E., 1995. The Panafrican stratoid granites of 
Madagascar: alkaline magmatism in a post-collisional extensional setting. Journal of Petrology 36, 1367-1391.

Norconsult Consortium, 2007. Mineral Resources Management Capacity Building Project, Republic of Mozambique. Component 2: Geological Infrastructure Development Project, Geological Mapping. Report of the National Directorate of Geology, Republic of Mozambique.

Paquette, J.L., Moine, B., Rakotondrazafy, M.A.F., 2003. ID-TIMS using the step-wise dissolution technique versus ion microprobe $\mathrm{U}-\mathrm{Pb}$ dating of metamict Archean zircons from NE Madagascar. Precambrian Research 121(1-2), 73-84.

Paquette, J.-L., Nédélec, A., 1998. A new insight into Pan-African tectonics in the EastWest Gondwana collision zone by U-Pb zircon dating of granites from central Madagascar. Earth and Planetary Science Letters 155, 45-56.

Pearce, J.A., 1996. Sources and settings of granitic rocks. Episodes 19(4), 120-125.

Pearce, J.A., Harris, N.B.W., Tindle, A.G., 1984. Trace element discrimination diagrams for the tectonic interpretation of granitic rocks. Journal of Petrology 25, 956-983.

Roland, N.W., 2004. Pan-African Granite-Charnockite Magmatism in Central Dronning Maud Land, East Antarctica: Petrography, Geochemistry and Plate Tectonic Implications. Geol. Jb. B96, 187-231.

Santosh, M., Tanaka, K., Yokoyama, K., Collins, A.S., 2005. Late NeoproterozoicCambrian Felsic Magmatism Along Transcrustal Shear Zones in Southern India: $\mathrm{U}-\mathrm{Pb}$ Electron Microprobe Ages and Implications for the Amalgamation of the Gondwana Supercontinent. Gondwana Research 8, 31-42.

Schott, B., Schmeling, H., 1998. Delamination and detachment of a lithospheric root. Tectonophysics 296, 225-247.

Stacey, J.S., Kramers, J.D., 1975. Approximation of terrestrial lead isotopic evolution by a two-stage model. Earth and Planetary Science Letters 26, 207-221.

Stern, R.J., 1994. Arc Assembly and continental collision in the Neoproterozoic East African orogeny - implications for the consolidation of Gondwana. Annual Reviews of Earth and Planetary Sciences 22, 319-351.

Thomas, R.J., De Waele, B., Schofield, D.I., Goodenough, K.M., Horstwood, M., Tucker, R.D., Bauer, W., Annells, R., Howard, K., Walsh, G., Rabarimanana, M., Rafahatelo, J.-M., Ralison, A.V., Randriamananjara, T., 2009. Geological evolution of the Neoproterozoic Bemarivo Belt, northern Madagascar. Precambrian Research 172, 279-300.

Tucker, R.D., Ashwal, L.D., Handke, M.J., Hamilton, M.A., Le Grange, M., Rambeloson, R.A., 1999. U-Pb geochronology and isotope geochemistry of the Archean and proterozoic rocks of north-central Madagascar. Journal of Geology 107(2), 135153.

Tucker, R.D., Kusky, T.M., Buchwaldt, R., Handke, M.J., 2007. Neoproterozoic nappes and superposed folding of the Itremo Group, west-central Madagascar Gondwana Research 12, 356-379.

Viola, G., Henderson, I.H.C., Bingen, B., Thomas, R.J., Smethurst, M., De Azavedo, S., 2008. Growth and collapse of a deeply eroded orogen: insights from structural and geochronological constraints on the Pan-African evolution of NE Mozambique. Tectonics 27, doi:10.1029/2008TC002284

Whalen, J.B., Currie, K.L., Chappell, B.W., 1987. A-type granites: geochemical 
characteristics, discrimination and petrogenesis. Contributions to Mineralogy and Petrology 95, 407-419.

Williams, H.M., Turner, S.P., Pearce, J.A., Kelley, S.P., Harris, N.B.W., 2004. Nature of the Source Regions for Post-collisional, Potassic Magmatism in Southern and Northern Tibet from Geochemical Variations and Inverse Trace Element Modelling. Journal of Petrology 45, 555-607.

\section{Figure list for Maevarano Paper}

Figure 1: Reconstruction of the East African Orogen, showing the palaeoposition of Madagascar in Gondwana, after Jacobs and Thomas (2004) and Thomas et al. (2009).

Figure 2: Simplified geological map of northern Madagascar, showing the outcrop pattern of the Maevarano Suite. The inset shows the main geological units of the whole of Madagascar. BE - Bemarivo Belt; AB - Anaboriana-Manampotsy Belt; AN - Antongil Craton; NT - Antananarivo Craton; IT - South Madagascar domains, including Itremo Group; VO - Vohibory Domain; NB- Northern Bemarivo terrane; SB - Southern Bemarivo terrane. The site of one of the dated samples is shown (RK7248A); other sample locations are shown on Fig. 3.

Figure 3: Geological map of the type area of the Maevarano Suite, in the Maevarano River valley south of Sandra Kota, showing the localities of three of the dated samples.

Figure 4: a) Typical Maevarano Suite landscape, with high mountain and valley outcrops; b) Typical unfoliated porphyritic granitoid of the main phase; c) Typical foliated porphyritic granitoid from margin of main phase pluton; d) Pegmatitic facies of main phase charnockite with dark-brown weathering orthopyroxenes and dark green hornblende; e) Foliated layered gabbro of early phase of Maevarano Suite intruded by coarse-grained pegmatite veins associated with the main phase; f) Foliated layered gabbro of early phase cut by foliated felsic sheets, in turn intruded by main phase granitoid (upper third of picture) with foliated margin. 
903 Figure 5: CL images of zircons from the dated samples, showing some of the analysed 904 spots: a) and b) - zircons from BT/07/12; c) and d) - zircons from BT/07/22; e) and f) 905 zircons from BT/07/25; g) and h) - zircons from RK7248A.

907 Figure 6: Tera Wasserburg data plots for the four dated samples. Error crosses at $2 \sigma$.

908 Data not corrected for common $\mathrm{Pb}$.

911 Figure 7: a-c) Harker plots for Maevarano Suite samples; d) Total Alkali vs Silica plot

912 for Maevarano Suite samples. Classification fields from Gillespie and Styles (1999) after

913 Le Bas et al. (1986). Alkalic/sub-alkalic division from Miyashiro (1974)

914

915 Figure 8: a) Plot of $\mathrm{A} / \mathrm{CNK}\left(\right.$ molar $\mathrm{Al}_{2} \mathrm{O}_{3} /\left(\mathrm{CaO}+\mathrm{Na}_{2} \mathrm{O}+\mathrm{K}_{2} \mathrm{O}\right)$ ) vs $\mathrm{A} / \mathrm{NK}($ molar $\left.916 \mathrm{Al}_{2} \mathrm{O}_{3} /\left(\mathrm{Na}_{2} \mathrm{O}+\mathrm{K}_{2} \mathrm{O}\right)\right)$ for Maevarano Suite samples. b): $(\mathrm{Y}+\mathrm{Nb})$ vs $\mathrm{Rb}$ granite

917 discrimination plot for granitoid samples from the Maevarano Suite, after Pearce et al.

918 (1984). Dashed line indicates field of other post-collisional granitoids from the East

919 African Orogen, from the Northern EAO, Mozambique, and Antarctica; data from Kuster

920 and Harms, 1998; Roland, 2004; Norconsult, 2007. c): Ga/Al vs Zr granite discrimination

921 plot for granitoid samples from the Maevarano Suite, after Whalen et al. (1985). Dashed

922 line indicates field of other post-collisional granitoids from the East African Orogen,

923 from Mozambique and Antarctica; data from Roland, 2004; Norconsult, 2007. d):

924 Granitoid samples from the Maevarano Suite plotted on the Y-Nb-Ce discrimination plot

925 for A-type granites of Eby (1992). Dashed line indicates approximate field of other post-

926 collisional granitoids from the East African Orogen, from the Northern EAO,

927 Mozambique, and Antarctica; data from Küster and Harms, 1998; Roland, 2004;

928 Norconsult, 2007.

930 Figure 9: Primitive mantle-normalised trace element patterns for selected samples from 931 the early phase (a), main phase (b) and late phase (c) of the Maevarano Suite.

932 Normalising factors from McDonough and Sun (1995). 
935 Table 1: Whole-rock major, trace and rare earth element data for all analysed samples.

936

937 Supplemental data tables

938

939 Table A: Geochronological data table for Sample BT/07/12

940

941 Table B: Geochronological data table for Sample BT/07/22

942

943 Table C: Geochronological data table for Sample BT/07/25

944

945 Table D: Geochronological data table for Sample RK7248A

946

947 Table E: Measured and certificated results for standards, measured with two analytical 948 batches in which the samples described in this paper were run.

949 


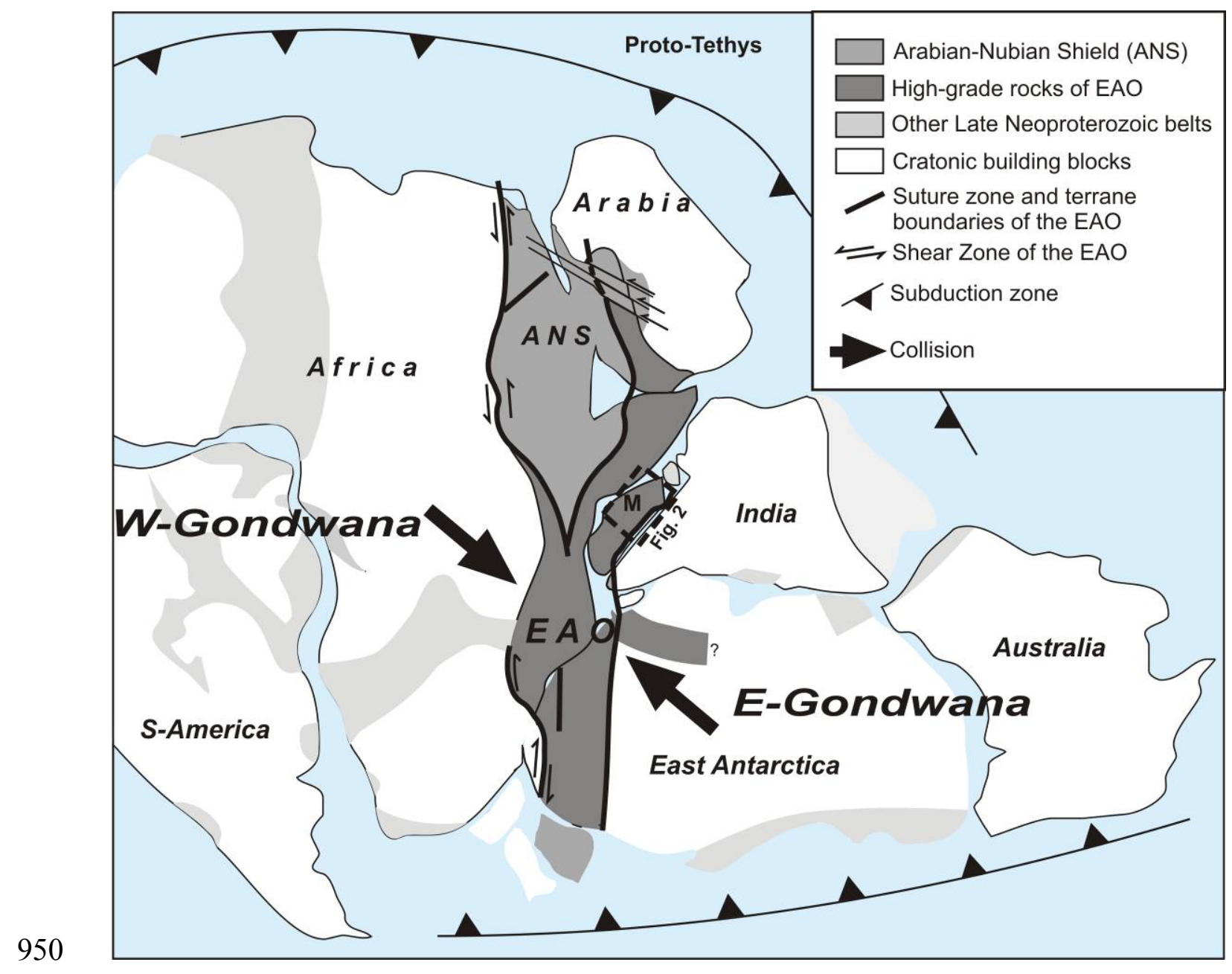

951 Fig. 1 


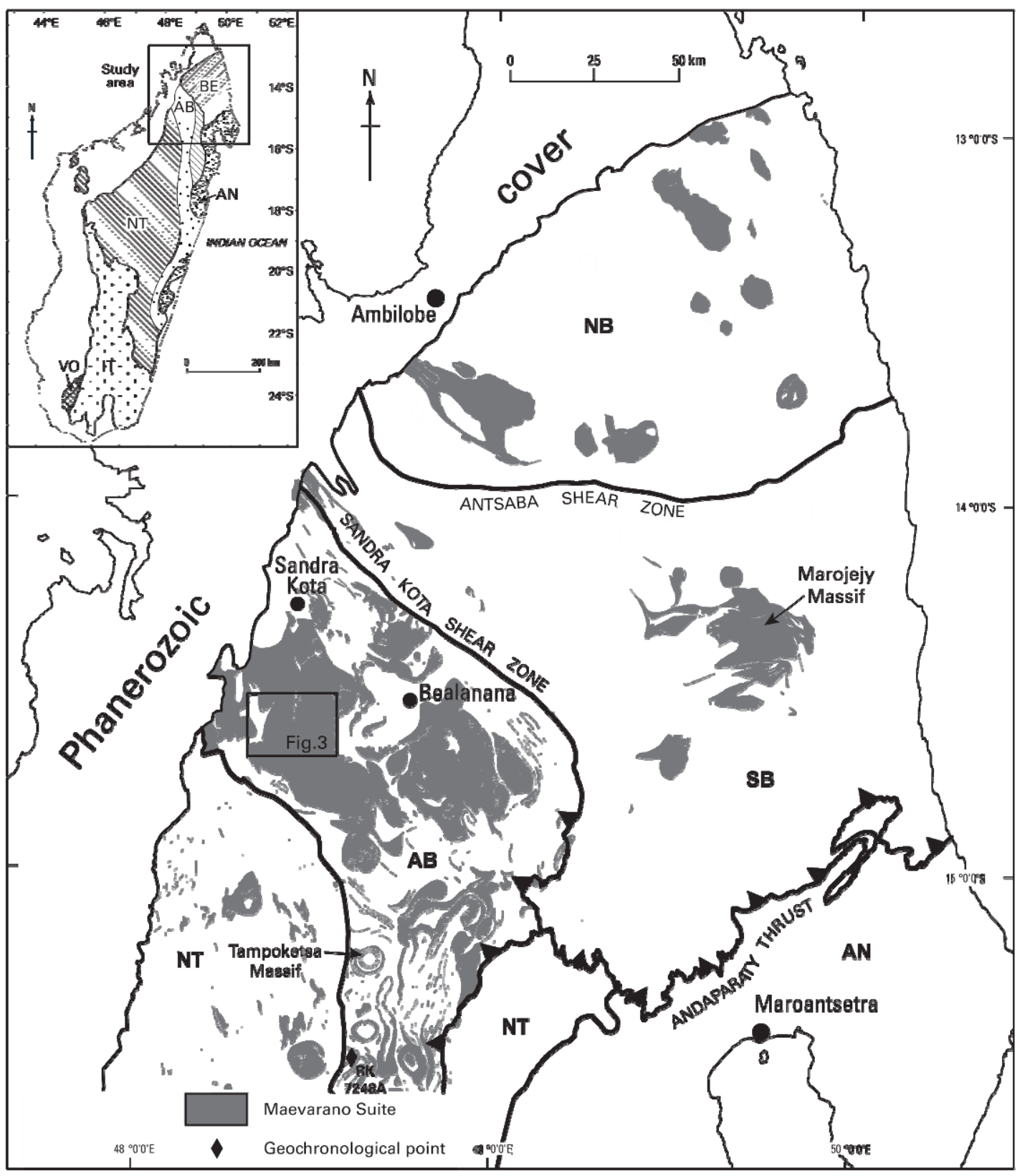

952

$953 \quad$ Fig 2 

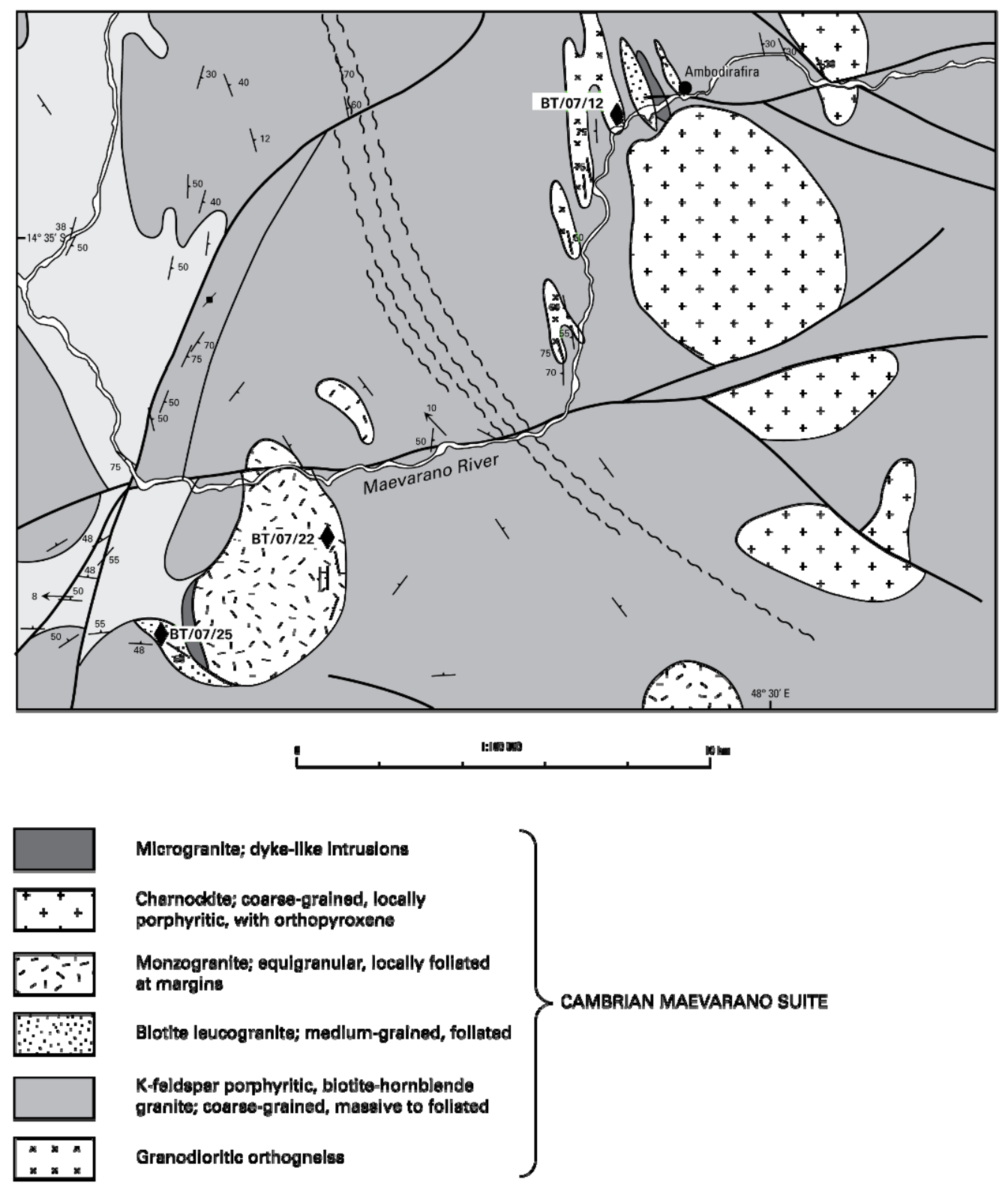

Mlerogranite; dyke-llke Intrusions

Chernockite; coerse-grained, locally porphyritic, with orthopyroxene

Monzogranite; equigranuler, locally follated at margins

CAMBRIAN MAEVARANO SUITE

Blotlte leucogranite; medlum-grained, follated

K-foldspar porphyritic, biotite-hornblende granite; coarse-grained, massive to foliated

Granodlorltle orthogneløs

Banded gneiss, stromstic, nebulitic and agmatitic migmatite, anatectic leucogranite

NEOPROTEROZOIC ANABORIANAMANAMPOTSY BELT
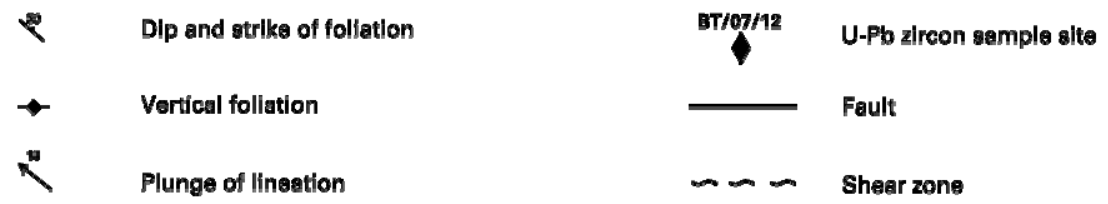

Fig 3 

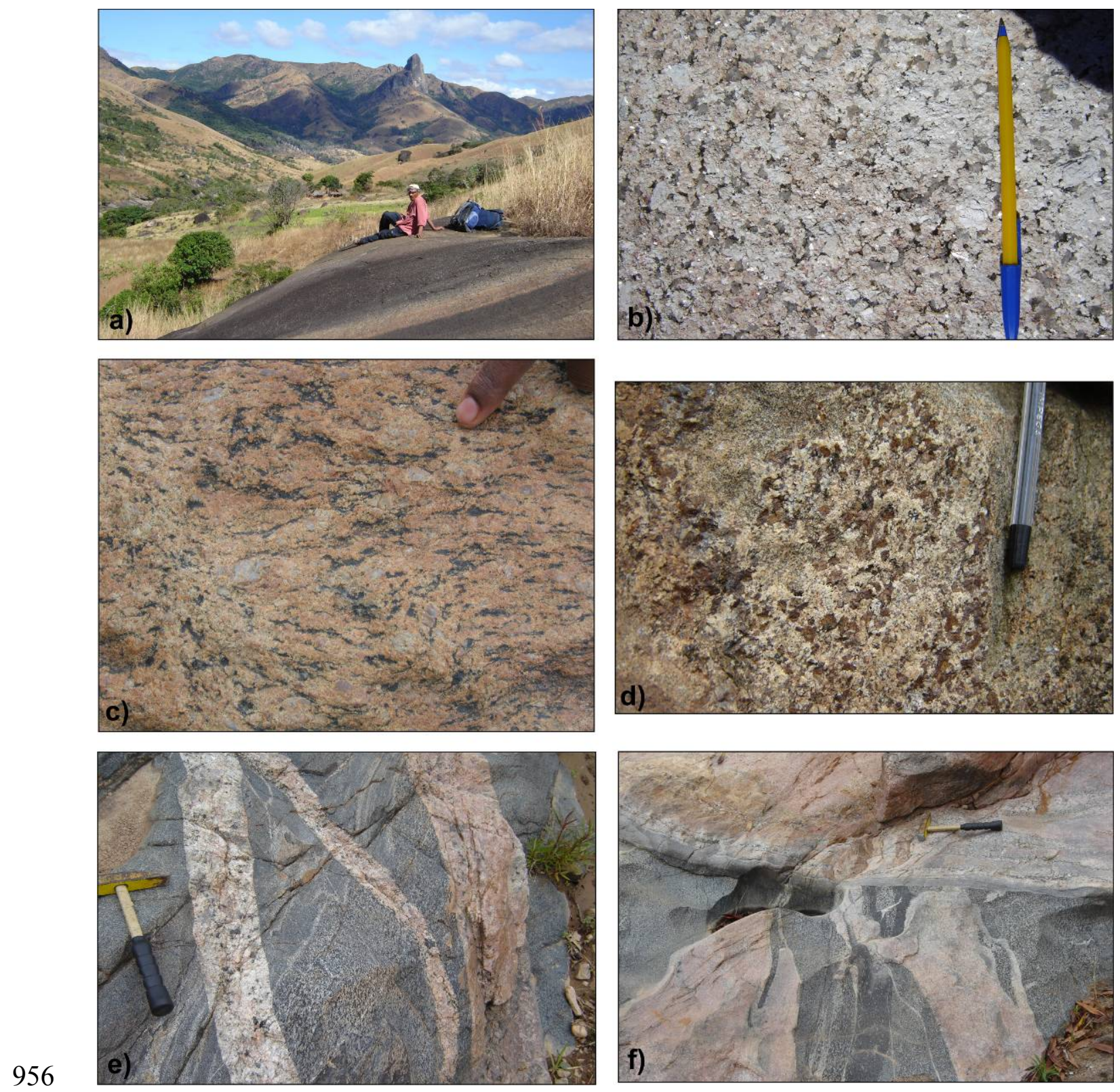

$957 \quad$ Fig 4 

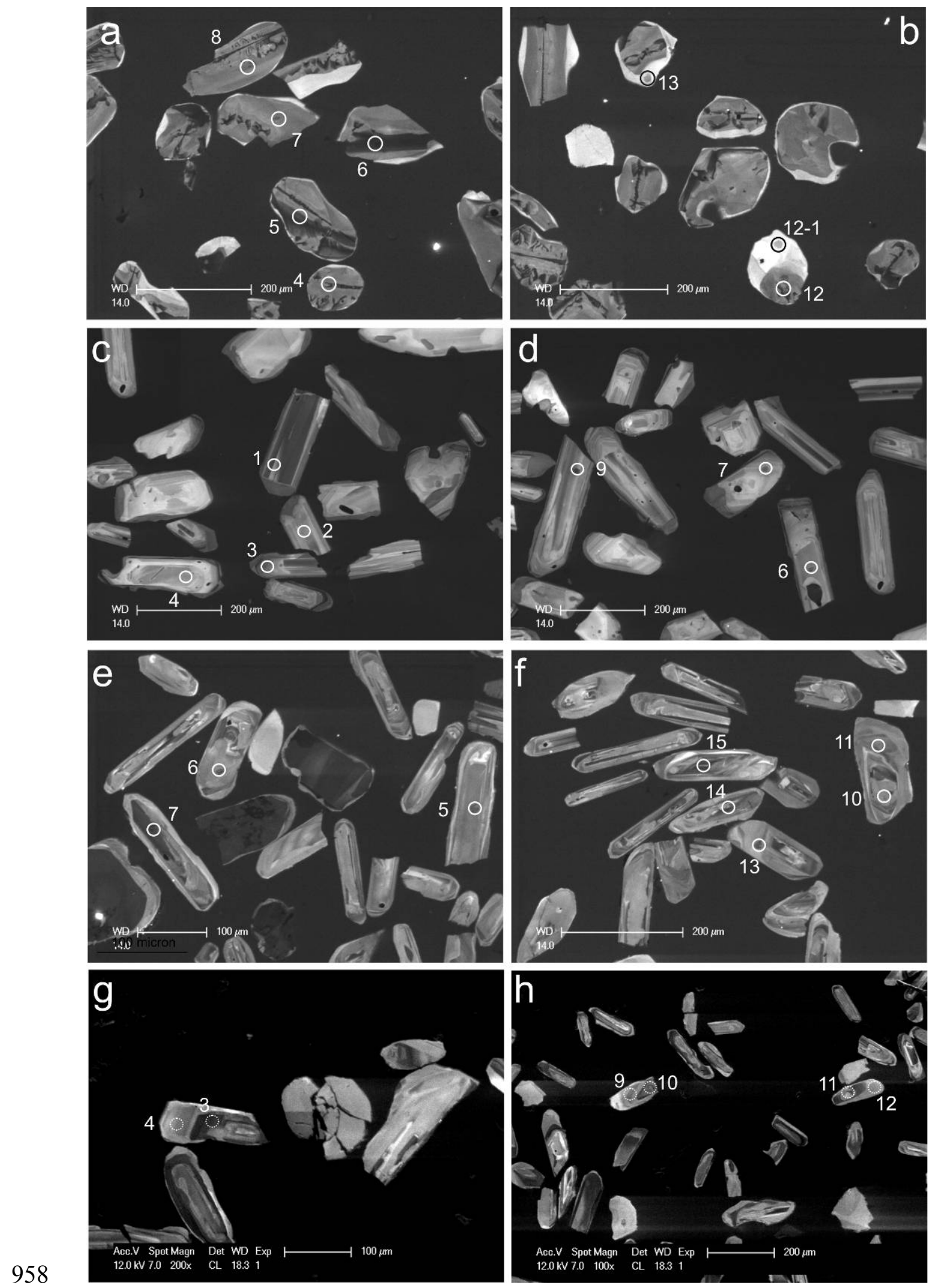

$959 \quad$ Fig 5 

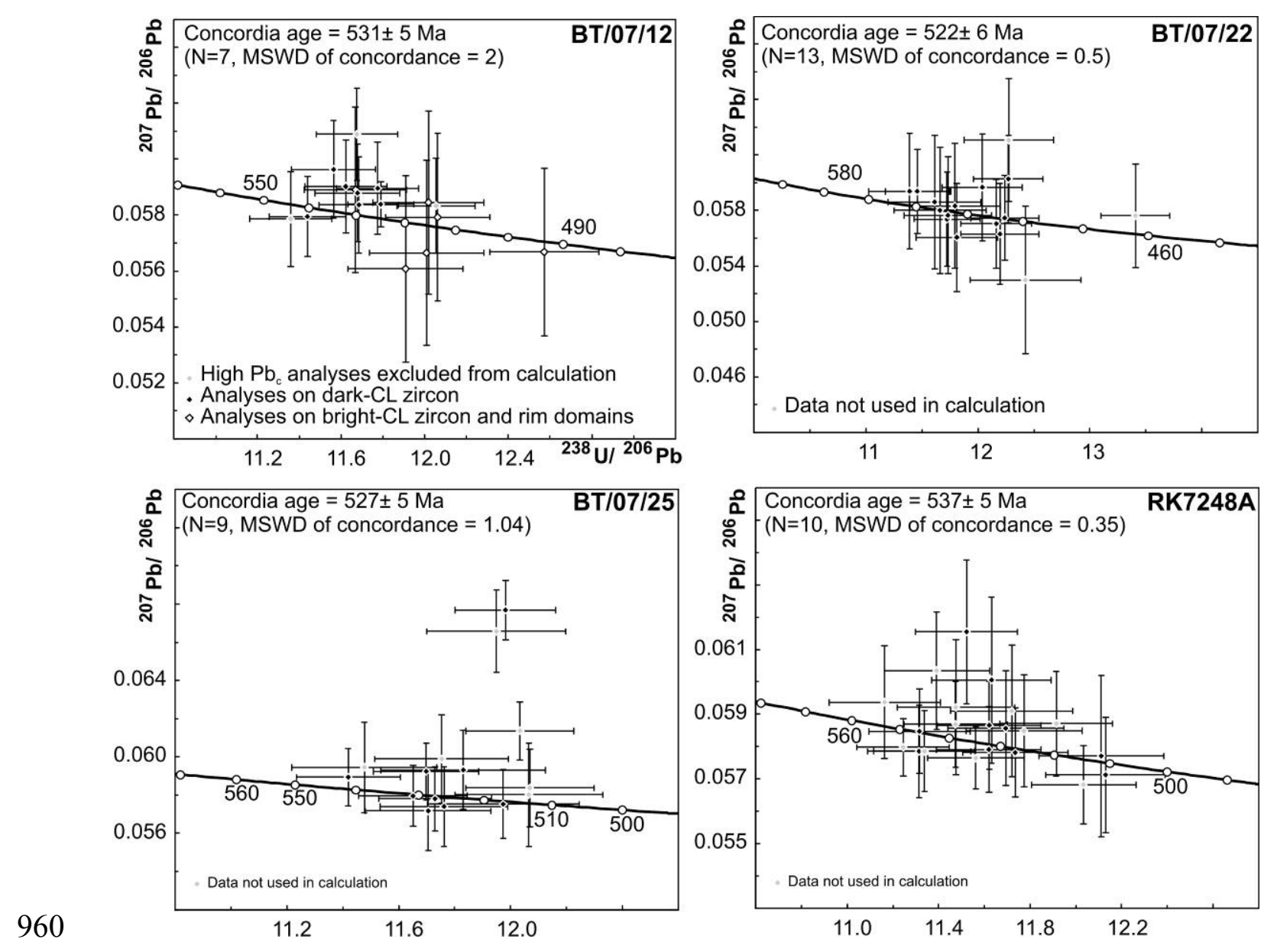

$961 \quad$ Fig 6 


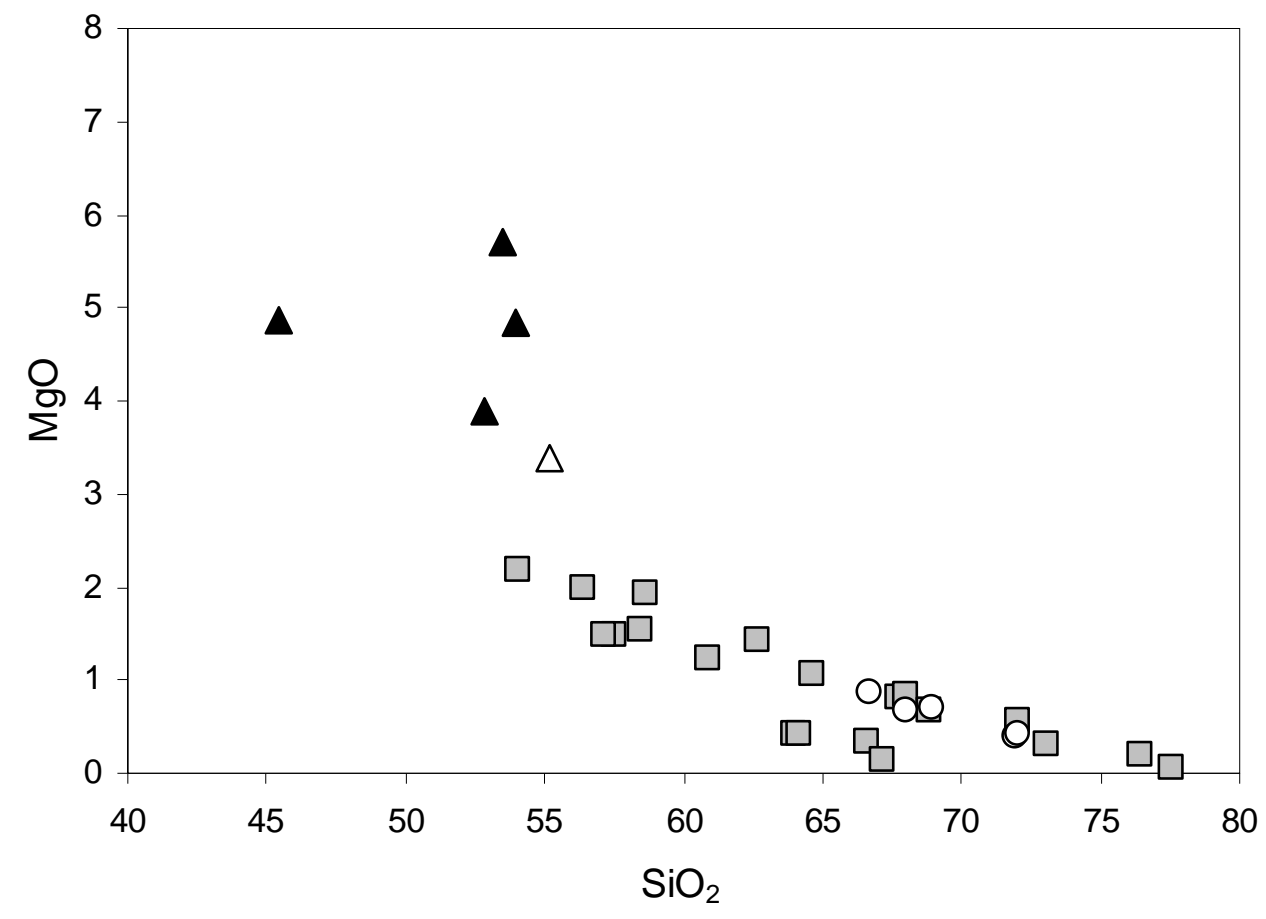

962

963 Fig. 7 a)

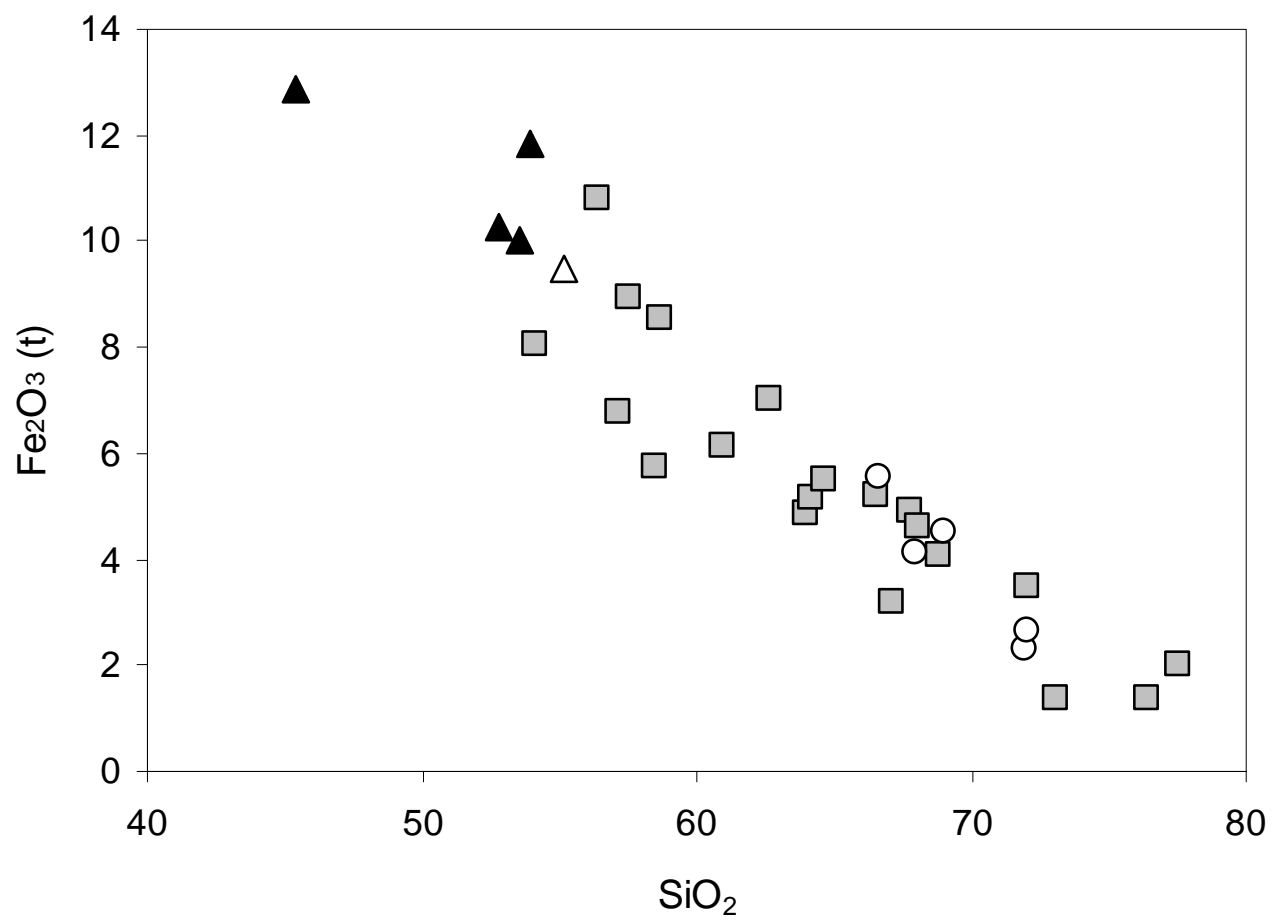

Fig. 7 b) 


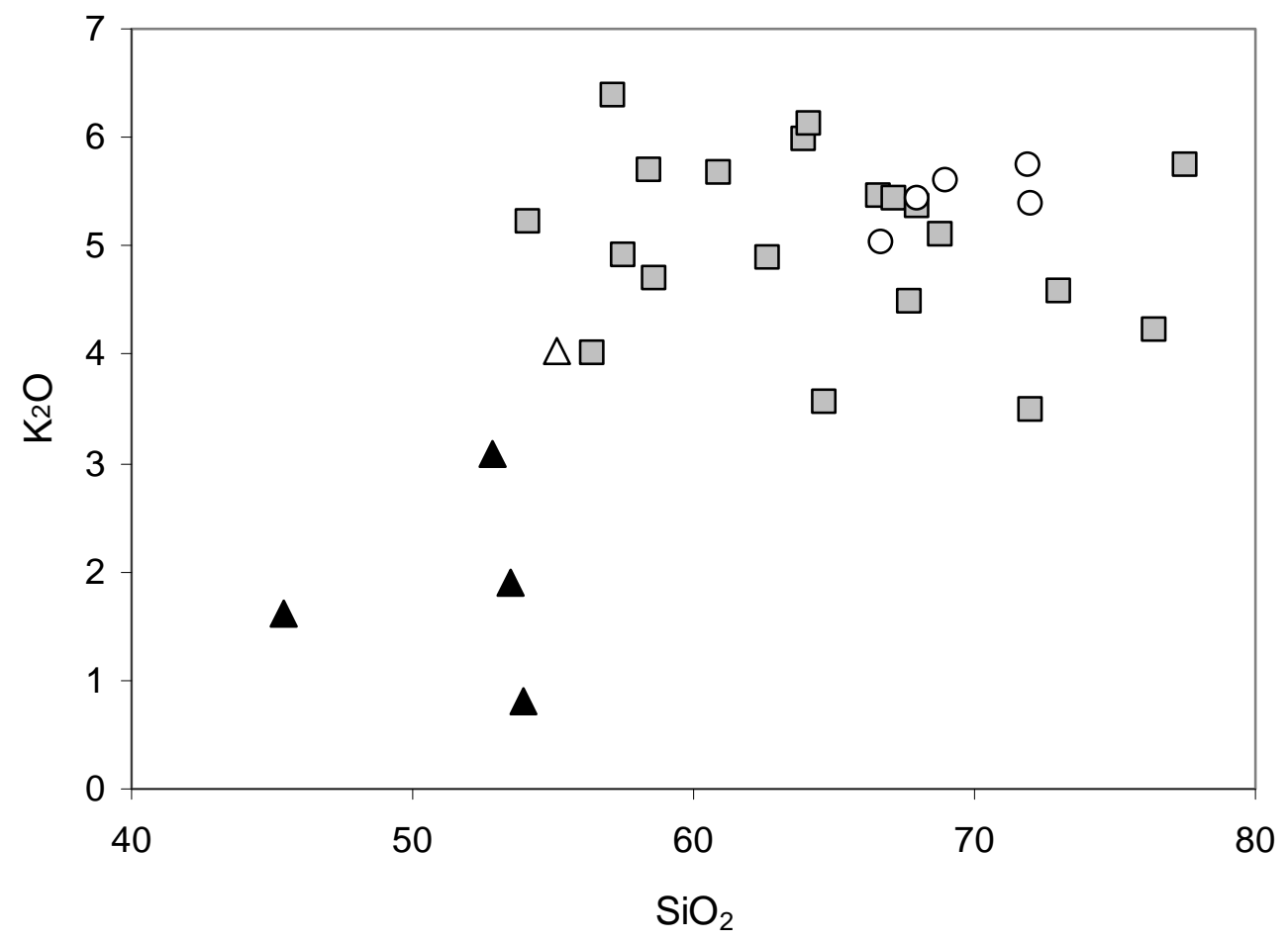

967

$\Delta$ Gabbro $\triangle$ Early phase $\square$ Main phase $O$ Late phase

$968 \quad$ Fig. 7 c)

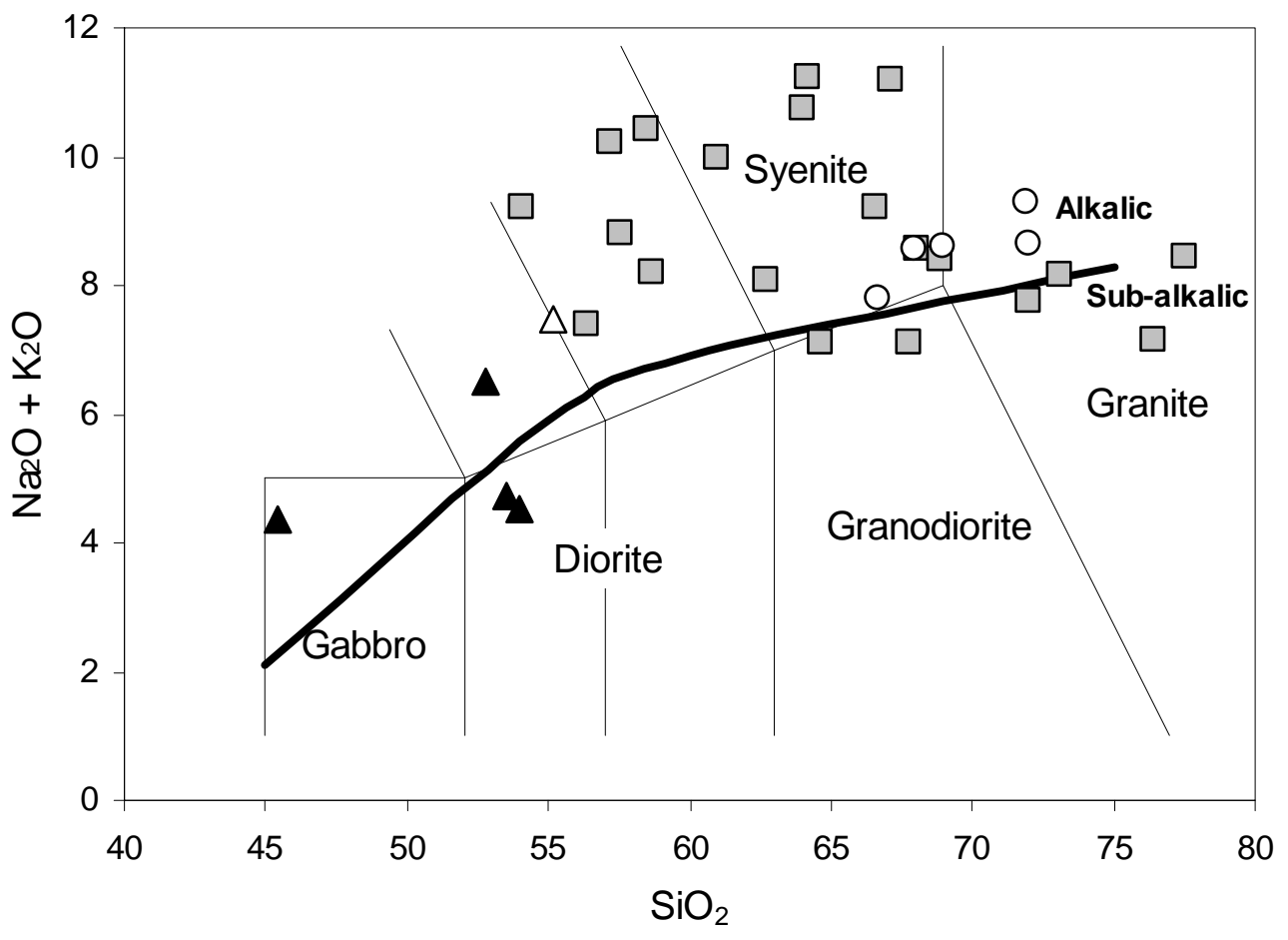

$\Delta$ Gabbro $\triangle$ Early phase $\square$ Main phase $O$ Late phase

Fig. 7 d) 


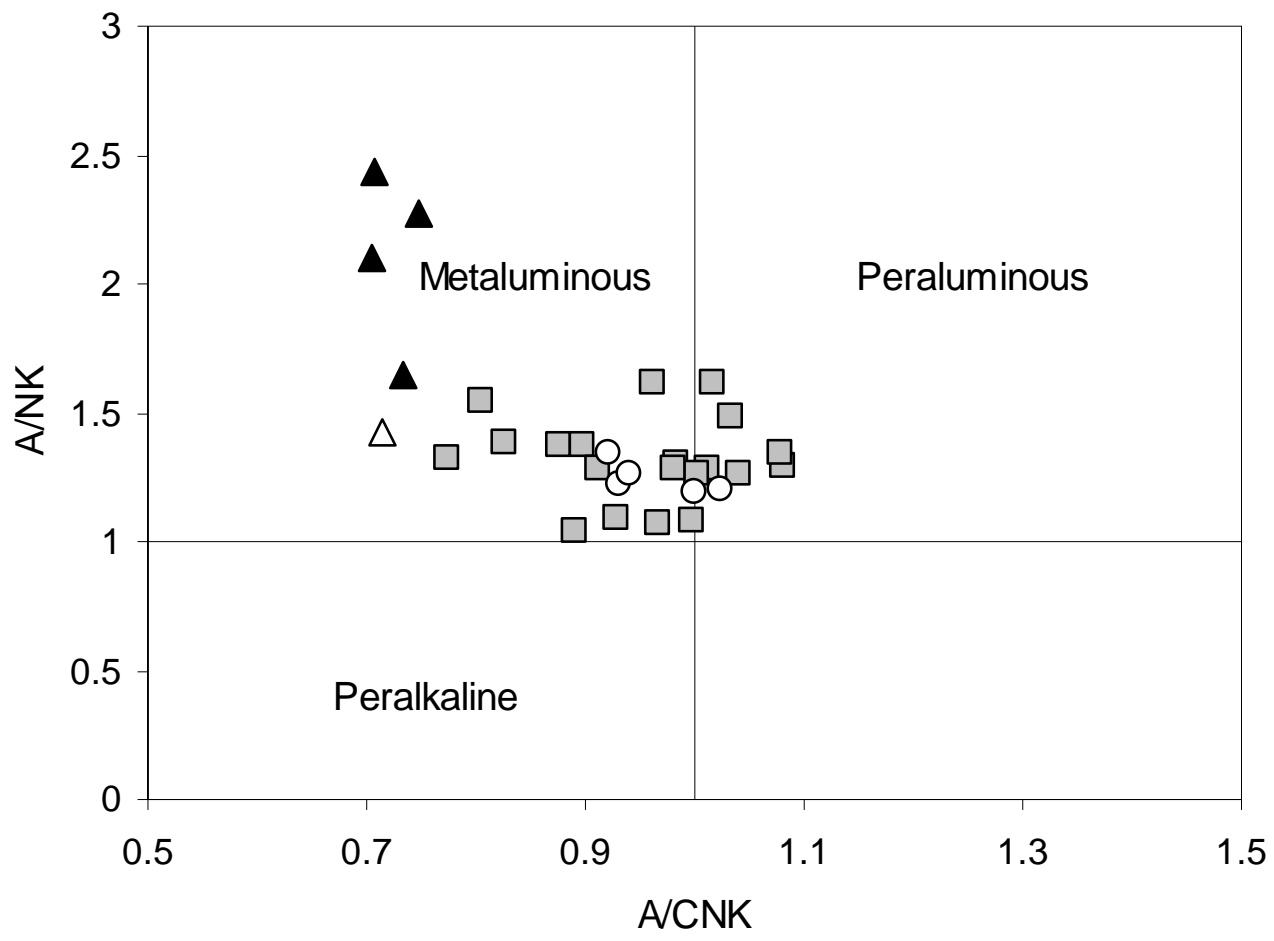

$\Delta$ Gabbro $\triangle$ Early phase $\square$ Main phase $\bigcirc$ Late phase

972 Fig. 8 a) 


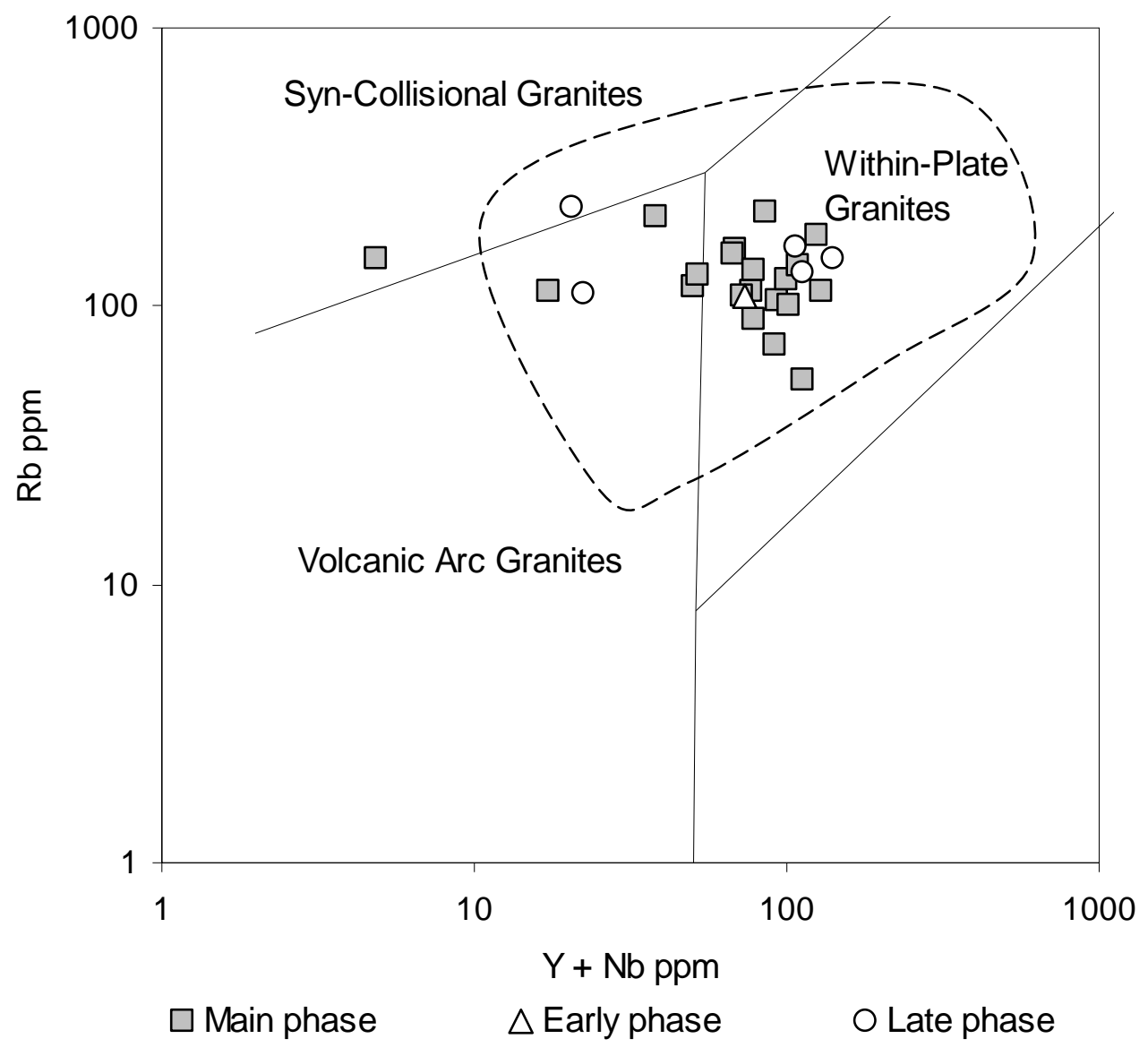

973

974 Fig. 8 b) 


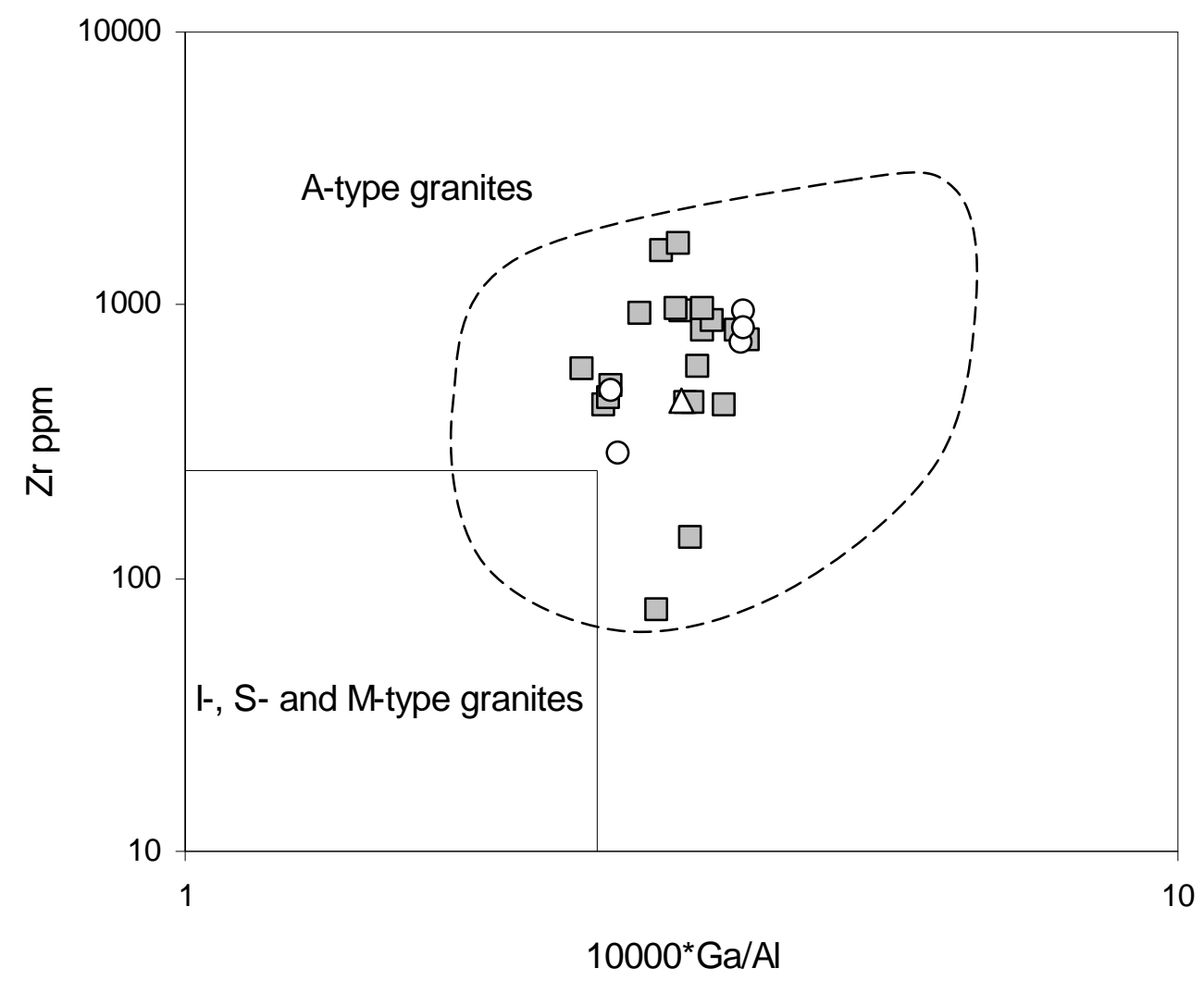

975

$\square$ Main phase $\triangle$ Early phase $\bigcirc$ Late phase

$976 \quad$ Fig. 8 c) 
977

978

Fig. 8 d)

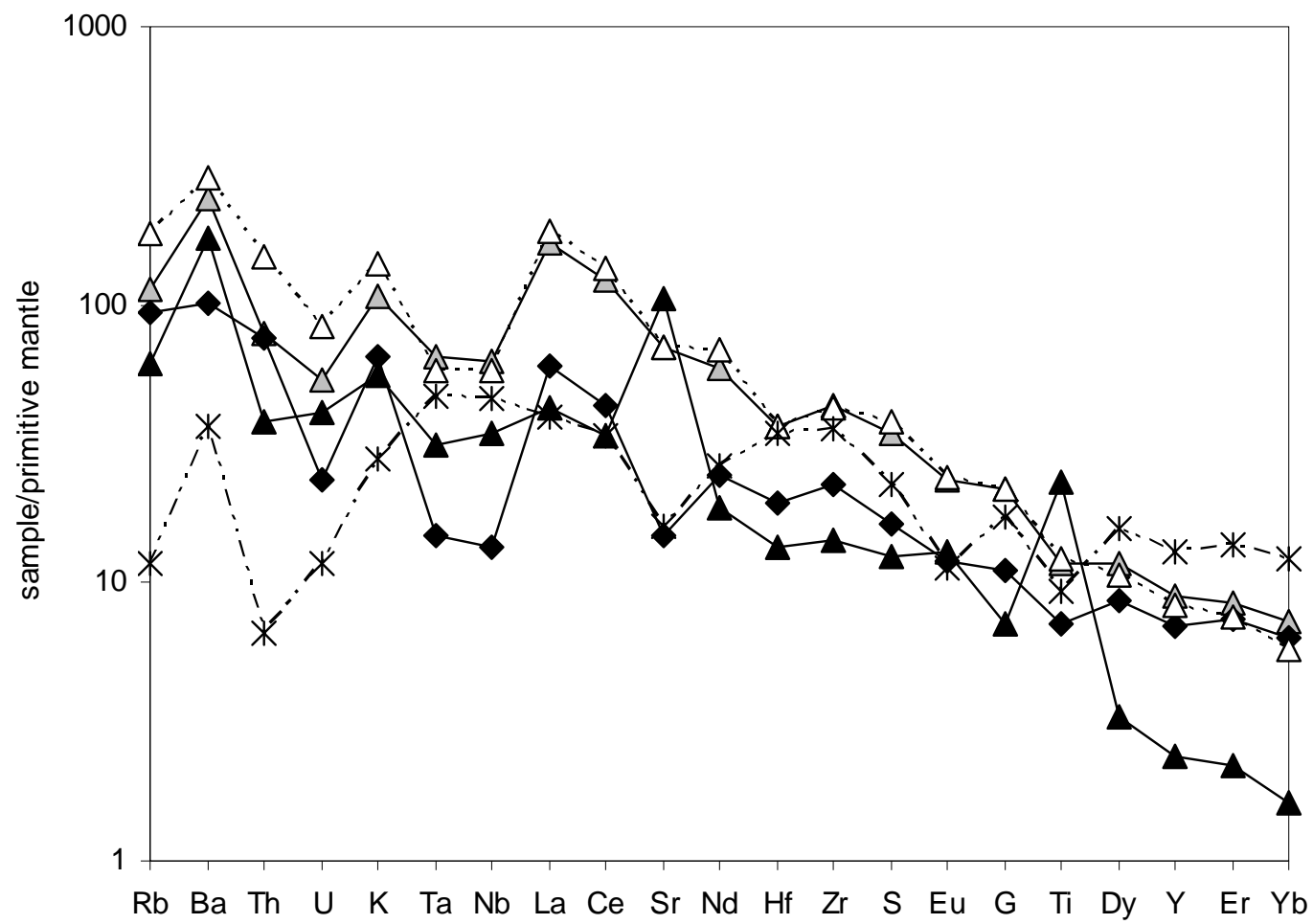

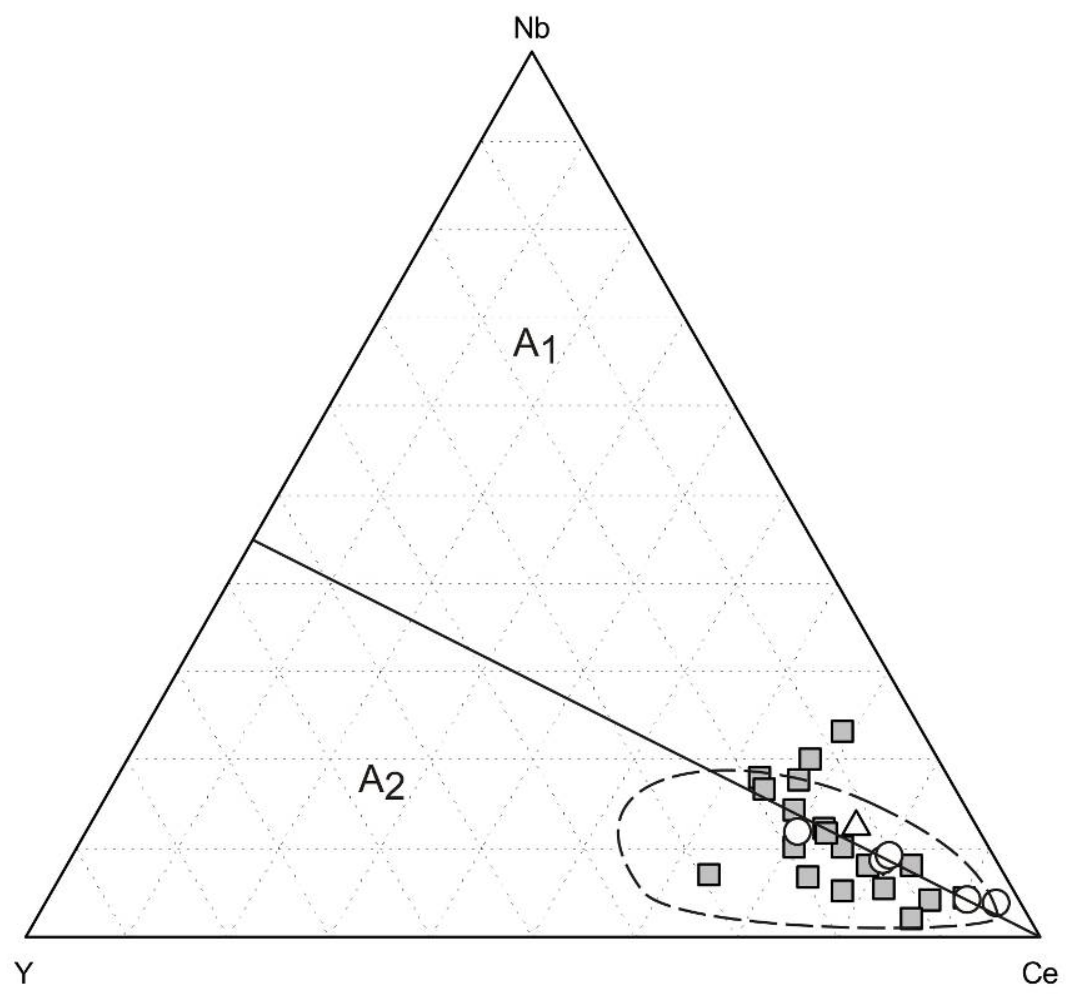

9 a) 


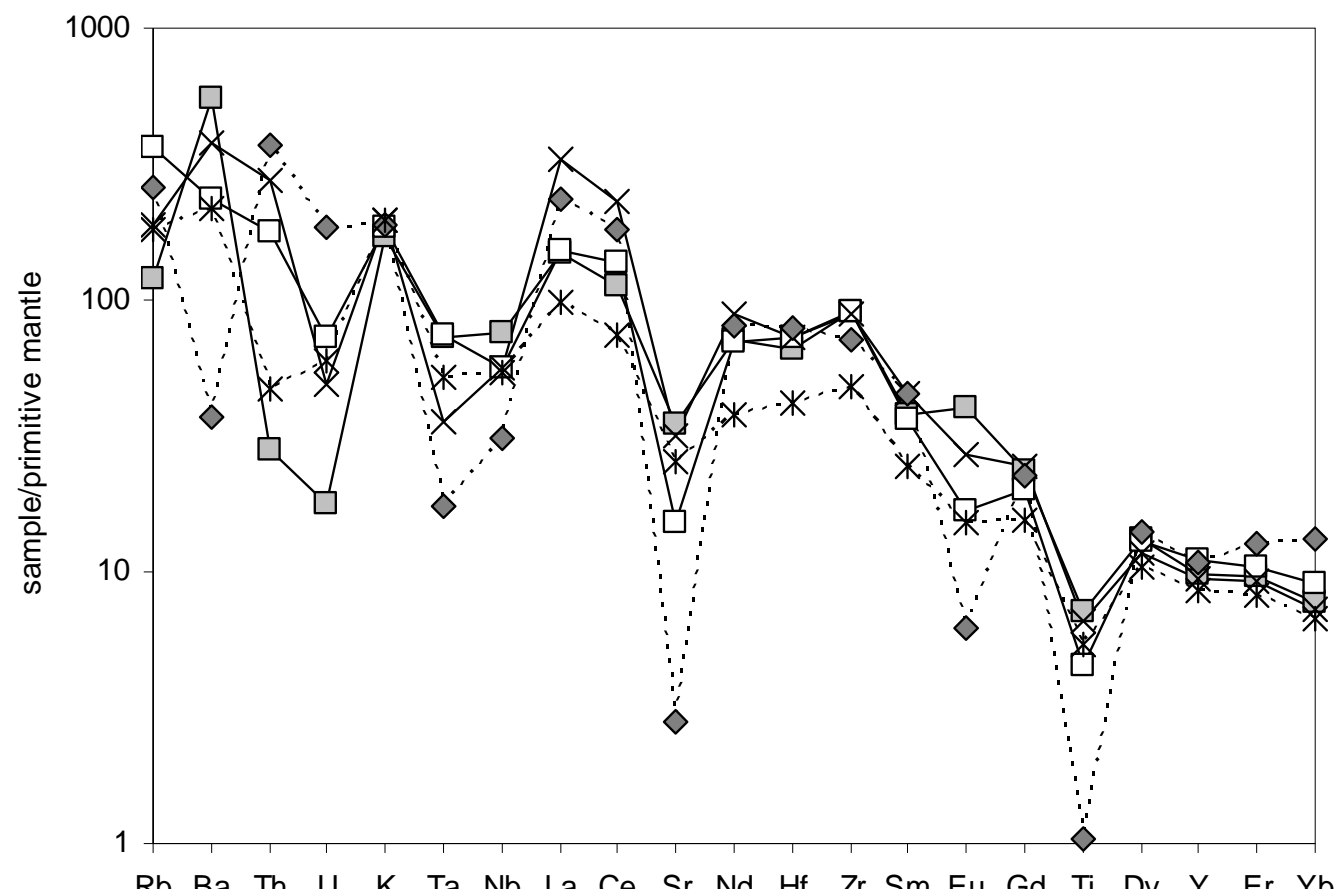

$\mathrm{Rb} B a$ Th $\mathrm{U}$ K Ta Nb La Ce Sr Nd Hf $\mathrm{Zr}$ Sm Eu Gd Ti Dy Y Er Yb

981

982

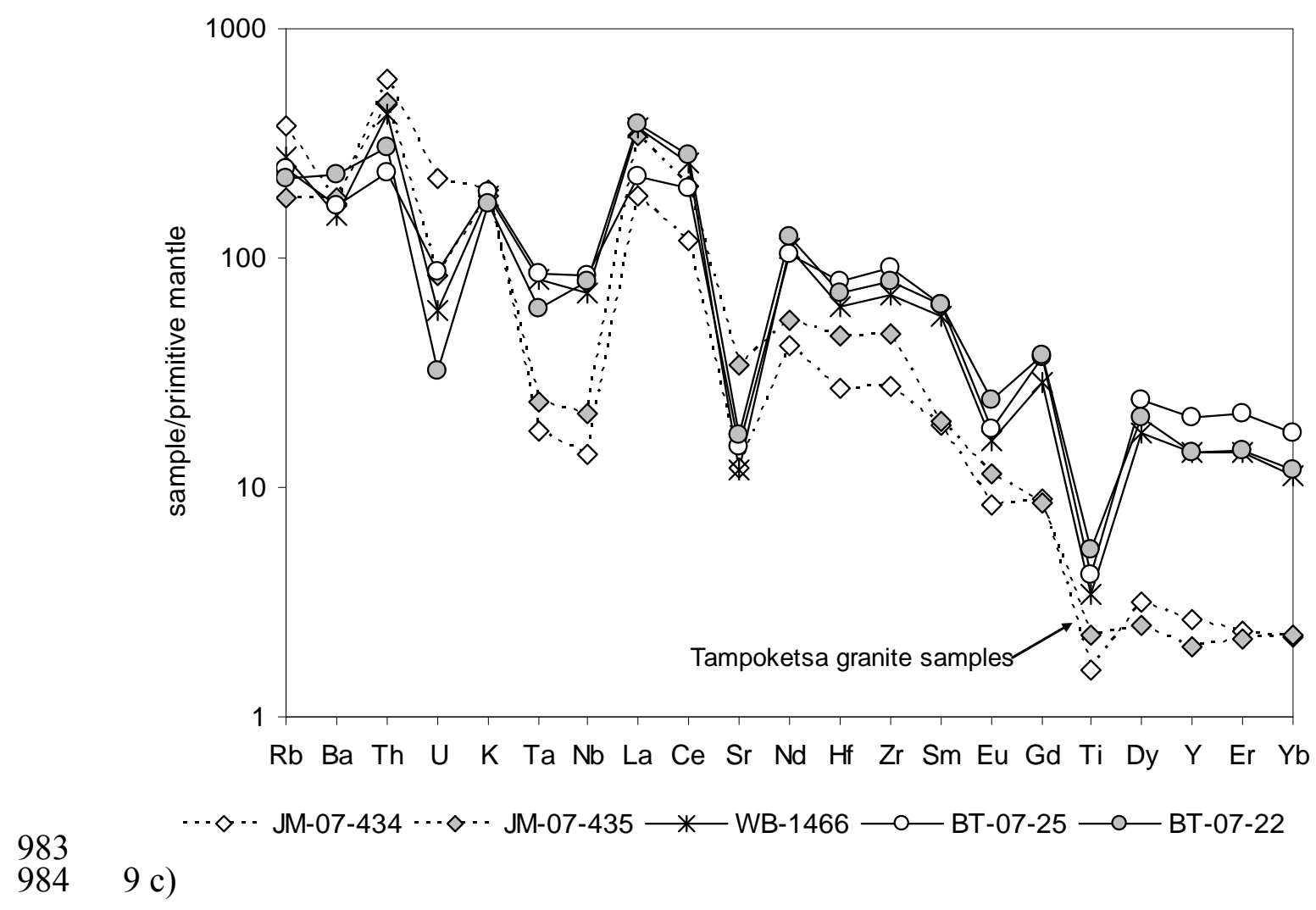

